Article

\title{
Form of Supplemental Selenium Affects the Expression of mRNA Transcripts Encoding Selenoproteins, and Proteins Regulating Cholesterol Uptake, in the Corpus Luteum of Grazing Beef Cows
}

\author{
Sarah N. Carr ${ }^{1}$, Benjamin R. Crites ${ }^{1}$, Joy L. Pate ${ }^{2}$, Camilla H. K. Hughes ${ }^{2,+}$, James C. Matthews ${ }^{1}$ \\ and Phillip J. Bridges ${ }^{1, *}$
}

check for

updates

Citation: Carr, S.N.; Crites, B.R.; Pate, J.L.; Hughes, C.H.K.; Matthews, J.C.; Bridges, P.J. Form of Supplemental Selenium Affects the Expression of mRNA Transcripts Encoding Selenoproteins, and Proteins Regulating Cholesterol Uptake, in the Corpus Luteum of Grazing Beef Cows. Animals 2022, 12, 313. https:// doi.org/10.3390/ani12030313

Received: 15 November 2021

Accepted: 21 January 2022

Published: 27 January 2022

Publisher's Note: MDPI stays neutral with regard to jurisdictional claims in published maps and institutional affiliations.

Copyright: (C) 2022 by the authors. Licensee MDPI, Basel, Switzerland. This article is an open access article distributed under the terms and conditions of the Creative Commons Attribution (CC BY) license (https:// creativecommons.org/licenses/by/ $4.0 /)$.
1 Department of Animal and Food Sciences, University of Kentucky, Lexington, KY 40546, USA; sarah.carr@uky.edu (S.N.C.); benjamin.crites@uky.edu (B.R.C.); james.matthews@uky.edu (J.C.M.)

2 Department of Animal Sciences, Center for Reproductive Biology and Health, The Pennsylvania State University, University Park, PA 16802, USA; jlp36@psu.edu (J.L.P.); camilla.hughes@umontreal.ca (C.H.K.H.)

* Correspondence: phillip.bridges@uky.edu

† Current Affiliation: Centre de Recherche en Reproduction et Fertilité, Faculté de Médecine Vétérinaire, Université de Montréal, St. Hyacinthe, QC J2S 2M2, Canada.

Simple Summary: In regions with selenium (Se) deficient soils, producers should supplement this mineral to the diet of forage-grazing cattle. Commercial supplements are typically formulated using inorganic forms of Se, but the organic forms are those naturally available in forages. We previously reported that circulating concentrations of progesterone are affected by the form of Se supplemented to cows. In this report, we aimed to determine (1) how the form of Se affects the expression of mRNA encoding selenoproteins in the corpus luteum, and (2) whether form of Se-induced increases in progesterone are the result of direct increases in the expression of steroidogenic transcripts. Cows were supplemented with the industry standard, an inorganic form of Se, or a 1:1 mix of organic and inorganic forms (MIX), with corpora lutea recovered on Day 7 of the estrous cycle. Transcripts encoding selenoproteins, as well as those regulating the uptake of cholesterol were affected by form of Se, but not those directly regulating steroidogenesis. We demonstrated that the expression of multiple selenoprotein mRNAs are affected by the form of Se, some of which are associated with intracellular antioxidant activity, and that the previously reported form of Se-induced increase in progesterone appears to be due to increased cholesterol availability by the corpus luteum, not by an increase in the expression of key steroidogenic enzymes.

Abstract: Selenium (Se)-deficient soils necessitate supplementation of this mineral to the diet of forage-grazing cattle. Functionally, Se is incorporated into selenoproteins, some of which function as important antioxidants. We have previously shown that the source of supplemental Se; inorganic (sodium selenite or sodium selenate; ISe), organic (selenomethionine or selenocysteine; OSe) or 1:1 mix of ISe and OSe (MIX), provided to Angus-cross cows affects concentrations of progesterone (P4) during the early luteal phase of the estrous cycle. In this study, we sought to investigate (1) the effect of form of Se on the expression of mRNA encoding selenoproteins in the corpus luteum (CL), and (2) whether this previously reported MIX-induced increase in P4 is the result of increased luteal expression of key steroidogenic transcripts. Following a Se depletion and repletion regimen, 3-year-old, non-lactating, Angus- cross cows were supplemented with either ISe as the industry standard, or MIX for at least 90 days, with the CL then retrieved on Day 7 post-estrus. Half of each CL was used for analysis of targeted mRNA transcripts and the remainder was dissociated for culture with select agonists. The expression of three selenoprotein transcripts and one selenoprotein $\mathrm{P}$ receptor was increased $(p<0.05)$, with an additional five transcripts tending to be increased $(p<0.10)$, in cows supplemented with MIX versus ISe. In cultures of luteal cells, hCG-induced increases in P4 $(p<0.05)$ were observed in CL obtained from ISe-supplemented cows. The abundance of steroidogenic transcripts in the CL was not affected by the form of Se, however, the abundance of mRNA encoding 2 key transcripts regulating cholesterol availability ( $L d l r$ and $H s l$ ) was increased 
$(p<0.05)$ in MIX-supplemented cows. Overall, the form of Se provided to cows is reported to affect the expression of mRNA encoding several selenoproteins in the CL, and that the form of Se-induced effects on luteal production of $\mathrm{P} 4$ appears to be the result of changes in cholesterol availability rather than a direct effect on the expression of steroidogenic enzymes within the CL.

Keywords: corpus luteum; selenium; selenoprotein; progesterone; cholesterol; steroidogenesis

\section{Introduction}

The physiological effects of a deficiency in selenium (Se) that occur as a result of cattle consuming forages from Se-deficient soils are well-documented [1-5]. In Se-deficient regions, including the southeast United States, it is recommended that cattle producers supplement this trace mineral to ensure adequate rates of growth [1], immune function [2,3], and reproductive health $[4,5]$. Naturally, Se can exist in various forms, including the organic forms, selenocysteine (SeCys) and selenomethionine (SeMet), and the inorganic forms, selenite and selenate [6]. Organic forms of selenium are the most predominant form in forages; however, inorganic forms are more commonly used in commercial vitamin-mineral mixes supplemented to livestock in selenium deficient regions such as the southeast United States [7].

The relevance of Se as a trace mineral was identified due to its role as a structural component of glutathione peroxidases (GPX's; [8]), a family of enzymes with antioxidant capabilities. Presently, there have been $>20$ genes for selenoproteins identified in humans [9] and pigs [10]. Many studies have demonstrated the antioxidant capabilities of selenoproteins to protect cells from harmful reactive oxygen species (ROS) [9,11-19]. GPX variants are some of the most common antioxidants that catalyze hydrogen peroxide into $\mathrm{H}_{2} \mathrm{O}$ [9], and thioredoxins protect against oxidative stress as redox proteins and can catalyze dithiol-disulfide exchange reactions in various tissues. Although thioredoxin is not a selenoprotein, once thioredoxin is oxidized, it must be reduced by the selenoproteins thioredoxin reductases (TRXR) [11]. Additionally, selenoprotein P (SELENOP [14]), selenoprotein W (SELENOW [15]), selenoprotein H (SELENOH [16]), selenoprotein K (SELENOK [17]), selenoprotein M (SELENOM [18]), and selenoprotein R (SELENOR [19]) have documented or proposed antioxidant properties.

Physiological incorporation of Se is dependent on its respective form [6] and the form of Se available for uptake affects the transcriptome profile in tissues including the liver [20], neonatal testis [21], and pituitary [22] of cattle. The form of dietary Se affects the bioavailability and bioactivity of this trace mineral in blood and tissues, altering concentrations of selenoproteins including GPX's [23-25]. Research has indicated differences in the assimilation of Se, dependent on the form being fed, with lower blood and milk concentrations of Se in cows supplemented with an inorganic (ISe) versus organic (OSe) form [25-32]. Previously, our lab demonstrated that a 1:1 blend of ISe and OSe (MIX) provided to cows to achieve a Se-adequate status resulted in a 1.0 to $1.7 \mathrm{ng} / \mathrm{mL}$ increase in early (Days 6 and 7) luteal phase concentrations of P4 when compared to cows supplemented with ISe and/or OSe alone [33,34]. This elevated P4 occurs without any effect on diameter of the CL [33]. Importantly, multiple trials have reported that development of the endometrium [35] and consequently growth of the conceptus [36,37] are advanced with elevated early luteal phase concentrations of $\mathrm{P} 4$, increasing overall indicators of fertility [38].

With no knowledge of how different forms of supplemental Se affect the expression of transcripts encoding selenoproteins in the $\mathrm{CL}$, nor of the mechanism by which supplementation with MIX increases early luteal phase $[33,34]$ or gestational [34] concentrations of systemic P4, the primary objectives of this study were to determine the effect of form of Se on (1) the relative abundance of mRNA transcripts that encode selenoproteins and targeted steroidogenic enzymes in the $\mathrm{CL}$, and (2) the ability of dissociated luteal cells to synthesize P4 and respond to key agonists in vitro. To achieve this goal, we assigned cows 
to form of Se-treatment regimens (ISe versus MIX) that achieved a Se-adequate status in all cows, then collected CL from these cows on Day 7 of the estrous cycle for molecular and in vitro analyses. We hypothesized that there would be form of Se-induced changes in the expression of selenoprotein mRNAs, that CL from MIX-treated cows would express an increase in enzymatic transcripts that favor the production of $\mathrm{P} 4$ by luteal cells, and an increased ability for these luteal cells to respond to exogenous agonists in vitro.

\section{Materials and Methods}

\subsection{Animals and Experimental Procedure}

All procedures involving animals were approved by the University of Kentucky's Institutional Animal Care and Use Committee (IACUC), protocol number 2017-2828. Fallborn, first-calf 3-year-old Angus-cross cows $(\mathrm{N}=10)$ were selected from established, Se form-specific cowherds as previously described [20,21,26,33]. At the beginning of this trial, all cows were subject to a 45-day period where systemic levels of Se were depleted (supplementation of a vitamin-mineral mix containing no exogenous source of Se), followed by a 45-day period where all cows received supplement formulated with 35 ppm Se as ISe (repletion, Figure 1) to return total blood Se in all cows to a Se adequate status $[24,39,40]$. Following this, cows were assigned to at least 90 days of individual access to ISe $(n=5$; Sodium selenite; Prince Agri Products, Inc., Quincy, IL, USA) or MIX ( $n=5 ; 1: 1$ ISe:OSe; SEL-PLEX; Alltech, Inc., Nicholasville, KY, USA). Cows were individually supplemented with their respective treatments using in-pasture Calan gates [26]. Jugular blood was collected for the determination of total whole blood Se from each cow at the start, middle and endpoint of the depletion and repletion periods, then monthly until the end of the trial, similar to methods previously described [26,33].

\begin{tabular}{|c|c|c|c|}
\hline $\begin{array}{l}\text { DEPLETION } \\
45 \text { days, No Se }\end{array}$ & $\begin{array}{l}\text { REPLETION } \\
45 \text { days, ISe }\end{array}$ & $\begin{array}{c}\text { TREATMENT } \\
\text { 90+ days, ISe or MIX }\end{array}$ & $\begin{array}{l}\text { LUTECTOMY } \\
\text { d7 post estrus }\end{array}$ \\
\hline
\end{tabular}

Figure 1. Experimental model of dietary supplementation. At the start of experimentation, cows were subject to a 45-day depletion during which they were supplemented with a Se-free vitaminmineral mix, followed by a 45-day repletion period during which cows were supplemented with a vitamin-mineral mix formulated to contain $35 \mathrm{ppm}$ ISe/cow/day. After repletion, cows were supplemented with a vitamin-mineral mix containing $35 \mathrm{ppm}$ of their respective treatment for at least 90 days prior to estrous synchronization with an i.m. injection of $25 \mathrm{mg}$ dinoprost tromethamine. On day 7 post-estrus, CL were collected via trans-vaginal lutectomy for analysis of key selenoproteinencoding and steroidogenic transcripts by real-time PCR and in vitro culture of dissociated luteal cells with select agonists.

\subsection{Diet}

Cows were initially maintained on a common, nontoxic endophyte-infected tall fescue pasture (Lacefield MaxQ II), then transferred to a common silage diet during the winter months (January-April). Forage samples for analysis of Se and trace minerals were collected for the duration of experimentation. Pasture concentration of Se in the forage was approximately $0.01 \mathrm{mg} \mathrm{Se} / \mathrm{kg}$ as fed and $0.04 \mathrm{mg} \mathrm{Se} / \mathrm{kg}$ dry matter (Dairy One Forage Testing Laboratory, Ithaca, NY, USA). The concentration of Se in the dietary corn silage was approximately $0.03 \mathrm{mg} \mathrm{Se} / \mathrm{kg}$ as fed and $0.08 \mathrm{mg} \mathrm{Se} / \mathrm{kg}$ dry matter (Dairy One Forage Testing Laboratory, Ithaca, NY, USA). Both are consistent with being classified as Se deficient $[41,42]$.

\subsection{Experimental Regimen}

Following the 90 days of treatment with supplemental Se in either ISe or MIX forms, cows were randomly treated i.m. with $25 \mathrm{mg}$ dinoprost tromethamine $\left(\mathrm{PGF}_{2 \alpha}\right.$; Lutalyse, Pfizer Animal Health, New York, NY, USA) to induce luteal regression and monitored for behavioral estrus (Day 0). Development of the preovulatory follicle and ovulation was confirmed via trans-rectal ultrasonography using a $5-8 \mathrm{MHz}, 66-\mathrm{mm}$ linear array transducer 
(Ibex Pro, E.I. Medical Imaging, Loveland, CO, USA). On days 5, 6, and 7 post-estrus, the diameter of the $\mathrm{CL}$ was determined by ultrasonography and blood $(8 \mathrm{~mL})$ was collected into additive-free tubes (Vacutainer, Becton, Dickinson and Company, Franklin Lakes, NJ, USA) for retrieval of serum and quantification of P4 via radioimmunoassay [43]. On Day 7, each $\mathrm{CL}$ was collected by supra-vaginal lutectomy, and immediately placed in ice-cold culture medium $(24$ mM HEPES-buffered Ham's F-12 $(1 \times)$ culture medium plus L-glutamine and sodium bicarbonate containing $0.5 \%$ bovine serum albumin and $20 \mu \mathrm{g} / \mathrm{mL}$ gentamicin) to be washed, weighed, and cut into two halves [44,45]. One-half of the CL was transported in the culture medium on ice to the laboratory for dissociation and culture of the fully differentiated luteal cells. The second half was divided into 8 pieces, each of which was immediately snap frozen in liquid nitrogen to be used for RNA extraction and quantitative transcript expression by real-time polymerase chain reaction (qPCR).

\subsection{Cell Culture}

Luteal tissue was handled, dissociated, and incubated following established protocol $[44,45]$. Briefly, luteal tissue was minced into $\sim 1 \mathrm{~mm}^{3}$ cubes and placed in $24 \mathrm{mM}$ HEPES-buffered Ham's F-12 $(1 \times)$ culture medium with L-glutamine and sodium bicarbonate (Gibco ${ }^{\circledR}$, Life Technologies Corporation ${ }^{\mathrm{TM}}$, Grand Island, NY, USA), containing $0.5 \%$ BSA (Fisher BioReagents, Fair Lawn, NJ, USA), $20 \mu \mathrm{g} / \mathrm{mL}$ gentamicin (Gibco ${ }^{\circledR}$, Life Technologies Corporation ${ }^{\mathrm{TM}}$, Grand Island, NY, USA), and 2000 U/g tissue collagenase type I (Worthington Biochemical Corporation, Lakewood, NJ, USA) to dissociate cells. Following dissociation, cells were re-suspended in Ham's F-12 solution with L-glutamine, sodium bicarbonate, HEPES buffer and gentamicin for the determination of cell numbers and viability.

Culture plates were prepared by coating each well in $250 \mu \mathrm{L}$ culture medium with $10 \%$ newborn calf serum (Gibco ${ }^{\circledR}$, Life Technologies Corporation ${ }^{\mathrm{TM}}$, Grand Island, NY, USA). Plates were incubated for $30 \mathrm{~min}$ and then washed with the serum-free medium. Luteal cells were plated at $0.6 \times 10^{6}$ cells $/ \mathrm{mL}$ in 24-well plates in serum free medium supplemented with L-glutamine and ITS $(5 \mu \mathrm{g} / \mathrm{mL}$ insulin, $5 \mu \mathrm{g} / \mathrm{mL}$ transferrin, and $5 \mathrm{ng} / \mathrm{mL}$ selenium, Corning ${ }^{\mathrm{TM}}$ Premix Universal Culture Supplement, Corning, NY, USA); and $20 \mu \mathrm{g} / \mathrm{mL}$ gentamicin. Steroidogenic cells were cultured with or without $\mathrm{PGE}_{2}(1$ and $50 \mu \mathrm{M} / \mathrm{mL}$, Cayman Chemical Company, Ann Arbor, MI, USA), LH (1 and $10 \mathrm{IU} / \mathrm{mL}$, NIH LH-S26), or hCG (10 and $50 \mathrm{ng} / \mathrm{mL}$, Sigma Aldrich, St. Louis, MO, USA). Treatment concentrations (low and high for each agonist) were based upon previous reports [46-52]. All treatments and agonist-free control groups were performed in triplicate wells within each replicate. Cultures were incubated at $37{ }^{\circ} \mathrm{C}$ in a $5 \% \mathrm{CO}_{2} / 95 \%$ air environment. Cultures were observed every $12 \mathrm{~h}$ during experimentation. All cultured wells were similarly confluent and did not display any loss of cells. Culture media were collected and replaced with fresh medium containing treatments every $24 \mathrm{~h}$ for a total of $96 \mathrm{~h}$ for subsequent determination of the concentration of P4 via RIA.

\subsection{Real-Time PCR}

Total RNA was extracted from 400-600 mg frozen luteal tissue using TRIzol Reagent (Invitrogen Corporation, Carlsbad, CA, USA) following the manufacturer's instructions. The purity and concentration of total RNA samples were analyzed using a NanoDrop ND-100 Spectrometer (Nanodrop Technologies, Wilmington, DE, USA). All samples had $260 / 280$ absorbance ratios of 1.97 or greater.

The quantification of relative mRNA was performed using real-time polymerase chain reaction (qPCR) using cDNA. To do so, $1 \mu \mathrm{g}$ of each cow's total RNA was reverse transcribed into cDNA using the SuperScript ${ }^{\mathrm{TM}}$ IV VILO $^{\mathrm{TM}}$ Master Mix with ezDNAse ${ }^{\mathrm{TM}}$ Enzyme (Invitrogen by Thermo Fisher Scientific, Vilnius, Lithuania). Additionally, a control reaction that did not contain reverse transcriptase was performed and analyzed via qPCR to ensure that products from the targeted transcripts were not obtained from genomic DNA contamination. 
The relative abundance of the following mRNA's was quantified: the iodothyronine deiodinases Dio1, Dio2, and Dio3, the glutathione peroxidases Gpx1, Gpx2, Gpx3, Gpx4, and Gpx6, the thioredoxin reductases Txnrd1, Txnrd2, and Txnrd3. Additionally, we investigated the following selenoprotein mRNA's: Selenof, Selenoh, Selenoi, Selenok, Selenom, Selenon, Selenoo, Selenop, Selenor, Selenos, Selenot, Selenov, Selenow, Sephs1, and Sephs2. Finally, we analyzed the selenoprotein P receptor mRNA's Lrp2, Lrp8, and Tfrc.

Next, the relative abundance of P4-associated enzymatic transcripts: Star, Cyp11a1, Hsd3b1, Ptgs2, and Ptges, the receptor transcripts: Lhcgr, Pgr, Pgrmc1, Pgrmc2, Paqr5, Paqr7, Paqr8, Ep1,Ep2, Ep3, Ep4, and Pgtfr, and transcripts of proteins associated with cholesterol availability: Ldl, Scarb1, Hsl, Npc1, and Npc2 were quantified. Primer sequences used in qPCR and GenBank accession numbers are listed in Tables S1 and S2. Real-time PCR procedures were performed using the Bio-Rad CFX Maestro ${ }^{\mathrm{TM}}$ thermal cycler (Bio-Rad, Hercules, CA, USA) with iTaq Universal SYBR ${ }^{\circledR}$ Green Supermix (Bio-RAD, Hercules, CA, USA). A total volume of $25 \mu \mathrm{L}$ was used in each qPCR reaction containing $5 \mu \mathrm{L}$ of cDNA, $1 \mu \mathrm{L}$ of a $10 \mu \mathrm{M}$ stock of each primer (forward and reverse), $12.5 \mu \mathrm{L}$ of 2 X SYBR Green PCR Master Mix, and $5.5 \mu \mathrm{L}$ of nuclease-free water. The relative amount of each transcript was calculated using the $2^{-\Delta \Delta C T}$ method [53]. Primer sets for genes of interest were designed and obtained from NCBI Primer-BLAST tool (https: / www.ncbi.nlm.nih. gov / tools / primer-blast/, accessed 12 October 2021) against RefSeq sequence.

All cDNA products were validated via DNA sequencing for verification of targets at Eurofins MWG Operon LLC (Louisville, KY, USA), as previously described [21,54]. The resulting sequences were then compared to the NCBI RefSeq mRNA sequences used for primer templates. The primer pair design, amplicon length of product, and product identity for each targeted transcript are shown in Tables S1 and S2. Three constitutively expressed genes ( $\beta$-actin, Hprt1, and Sdha) with CT values not affected ( $p>0.05)$ by Se-form treatment were used to normalize the relative mRNA expression to the geometric mean of these three genes. For qPCR analysis, $n=5$ and 5 for ISe and MIX treatments, respectively. All reactions were performed in triplicate.

\subsection{Se and P4 Analysis}

Total blood Se was assayed by the American Associates for Veterinary Laboratory Diagnosticians-approved University of Kentucky Veterinary Diagnostics Laboratory (Lexington, KY, USA), as previously reported [55].

In both samples of serum and in vitro media, concentrations of P4 were quantified by a commercially available competitive RIA without extraction (ImmuChem ${ }^{\mathrm{TM}}$ Coated Tube Progesterone 125-I RIA Kit, MP Biomedicals, Costa Mesa, CA, USA), as described previously [31]. There was one assay performed for analysis of the serum with an intraassay $\mathrm{CV}$ of $5 \%$, and there were seven assays performed for analysis of culture media with inter-assay CV of 7.85\% and intra-assay CVs ranging from $4.53-9.43 \%$.

\subsection{Statistical Analysis}

In all statistical analyses, an individual cow was the experimental unit. All data were analyzed for a normal distribution and homogeneity of variance. When appropriate, data were natural log-transformed for normality. Results are presented as Least Square Means (LS Means) \pm standard error of the mean (SEM). At $p<0.05$ significance was declared, with a tendency to differ when $0.05 \leq p<0.10$. The effect of treatment on concentrations of peripheral Se and P4 were analyzed as an ANOVA with repeated measures using the PROC MIXED function of SAS statistical software package (version 9.4; SAS Institute, Inc., Cary, NC, USA). The form of dietary Se was considered the fixed effect for both, and the P4 data were natural log-transformed due to not being normally distributed. Luteal weight, luteal diameter, and relative abundance of all mRNA transcripts were analyzed using a Student's $t$-Test with the PROC TTest function of SAS statistical software package (version 9.4; SAS Institute, Inc., Cary, NC, USA). In vitro concentrations of P4 were analyzed using a split plot design for repeated measures (culture time) with Se treatment as the main-plot and 
LH, PGE 2 , and hCG as the sub-plot factors. Data were blocked by CL (cow) and natural log transformed due to data not being normally distributed or homologous. Data were analyzed as a mixed ANOVA using the PROC GLIMMIX function of the SAS statistical software package (version 9.4; SAS Institute, Inc., Cary, NC, USA).

\section{Results}

\subsection{Concentrations of Se in Whole Blood}

All cows were maintained on their respective Se-form treatments (ISe vs. MIX) and concentrations of whole blood Se were adequate throughout the duration of this study (Figure 2, [39,40]). During the depletion period, whole blood concentrations of Se declined for both treatment groups, and subsequently increased during the period of repletion. On each treatment, the ISe supplemented cows had a numerically greater concentration of peripheral Se compared to the MIX treatment group. However, within each group, the levels remained relatively stable until the experimental endpoint. There was no effect $(p>0.05)$ of form of Se at any time point during the study. There was an effect of time $(p<0.0001)$, but there was no treatment $X$ time interaction $(p>0.1)$.

\section{Concentration of total Se} in whole blood

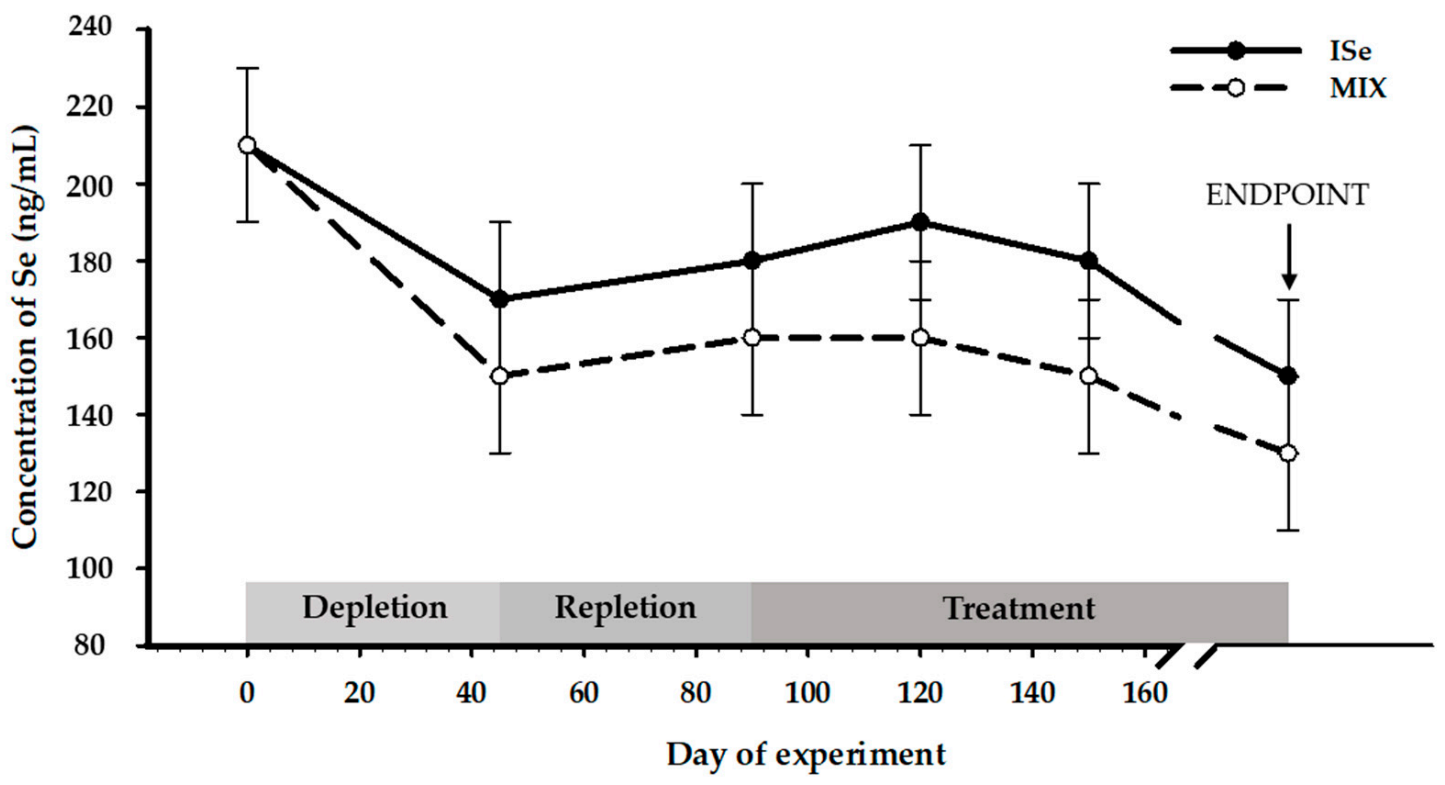

Figure 2. Effect of treatment (form of Se) on concentrations of Se in whole blood (ppm; LS Mean \pm SEM) of Se in cows supplemented with either ISe (Sodium selenite; $n=5$ ) or a 1:1 combination (MIX) of ISe and OSe (Sel-Plex; $n=5$ ). Data were analyzed as an ANOVA with repeated measures. Whole blood Se was not affected by treatment $(p=0.2393)$ but was affected by time $(p<0.0001)$.

\subsection{Real-Time RT-PCR Analysis of Selenoprotein and Receptor mRNA Transcripts}

Twenty-six transcripts encoding selenoproteins and three transcripts encoding receptors for selenoprotein P were targeted via QPCR analysis. The MIX form of supplemental Se significantly $(p<0.05)$ increased the abundance of four key transcripts encoding Gpx6, Selenor, Selenov, and Tfrc in the CL (Figure 3 and Table 1). Additionally, the relative abundance of Dio2, Gpx1, Gpx3, Selenoh, and Selenop tended $(0.05 \leq p<0.1)$ to be increased in the MIX treatment group. The relative level of expression of the other targeted selenoprotein transcripts or selenoprotein P receptors was not affected by treatment (Table 1). 


\section{Relative expression of mRNA transcripts encoding selenoproteins}

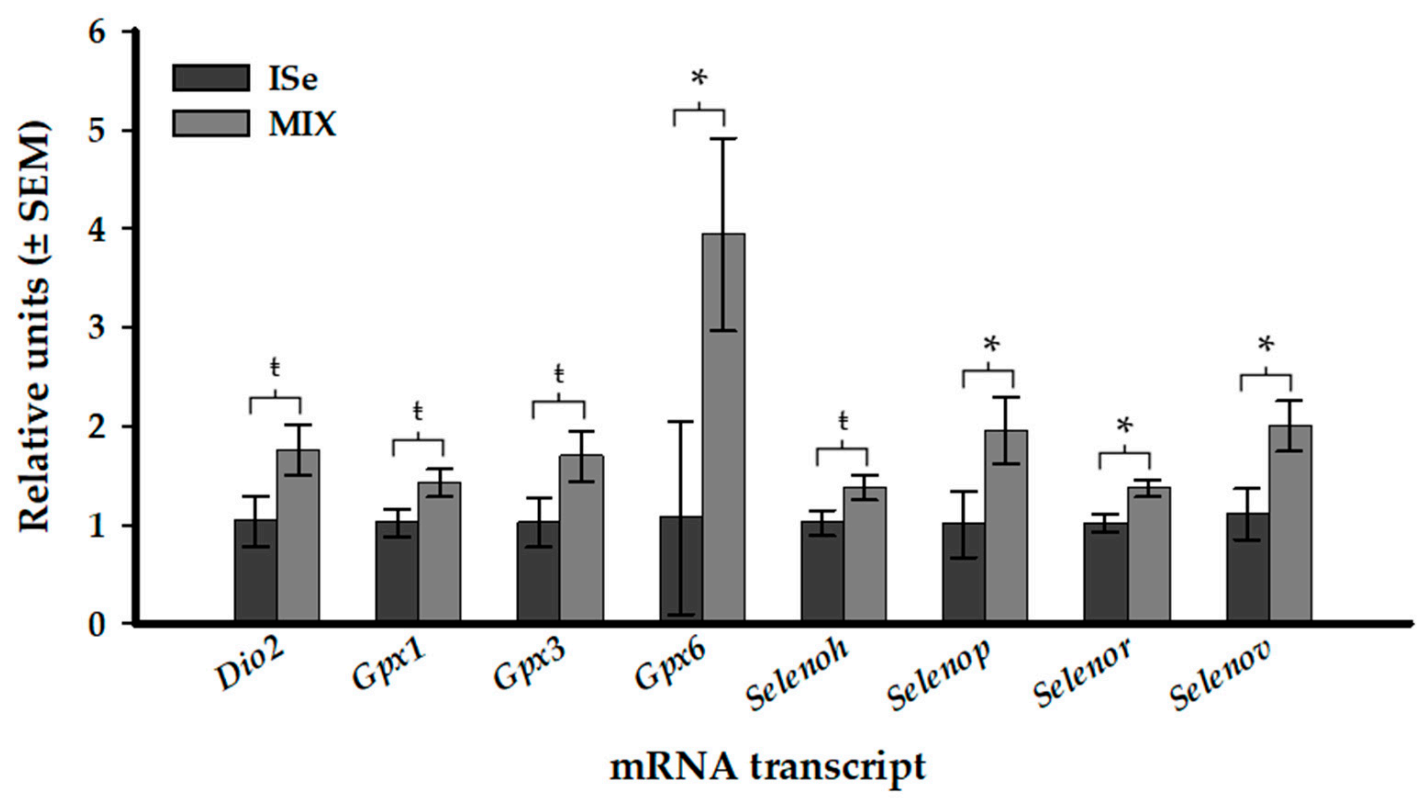

Figure 3. Effect of form of Se on the expression of mRNA transcripts encoding selenoproteins in the CL of cows supplemented with vitamin mineral mixes containing Se as ISe (sodium selenite; $n=5$ ) or a 1:1 combination (MIX) of ISe and OSe (Sel-Plex; $n=5$ ). $p$-values are associated with Student's $t$-Test. Significant differences at $p<0.05$ are indicated by an asterisk and tendencies at $0.05 \leq p<0.1$ are indicated by $t$.

\subsection{Concentrations of P4, Luteal Weight, and Luteal Diameter}

The concentration of P4 was quantified in serum collected on Days 5, 6 and 7 of the estrous cycle. Although in the present study there was no observed effect of form of Se on systemic P4 (Table 2, Year 3), the difference of $\sim 1 \mathrm{ng} / \mathrm{mL}$ between the treatment groups on Day 7 is consistent with previous studies from our lab $[33,34]$ that used a larger number of animals (Table 2, Year 1 and Year 2). Additionally, there was no difference $(p>0.05)$ in the weight or the diameter of the CL, consistent with our previously reported results [33].

\subsection{Production of Progesterone In Vitro}

Luteal production of $\mathrm{P} 4$ was determined in vitro by treating dissociated luteal cells with or without a low or high concentration of three agonists, $\mathrm{PGE}_{2}, \mathrm{LH}$, or hCG, for $96 \mathrm{~h}$. Culture media was collected every $24 \mathrm{~h}$ for quantification of P4. Across all dietary and agonist treatments, there was a significant effect of time of culture $(p<0.0001)$ as concentrations of $\mathrm{P} 4$ in the culture media decreased with each subsequent $24-\mathrm{h}$ period. There was a significant interaction $(p<0.0001)$ between time in culture and agonist treatment. There was no significant three-way interaction $(p>0.05)$ of dietary treatment, agonist treatment, and time in culture.

In basal, untreated cultures, there was no significant difference $(p>0.1)$ between dietary treatment groups in the production of P4; however, there tended $(199.5 \pm 13.9 \mathrm{vs}$. $163.0 \pm 8.9, p=0.07$ ) to be a greater concentration of P4 in the media collected at $48 \mathrm{~h}$ from CL retrieved from MIX-treated cows compared to ISe-treated cows (Figure 4).

After $24 \mathrm{~h}$ of culture, both the low and high doses of hCG increased the production of P4 in luteal cells collected from cows supplemented with ISe compared to MIX $(p<0.05$, Figure $5 \mathrm{~A}, \mathrm{~B})$, an unexpected result. There was no other significant difference at $24 \mathrm{~h}$ in vitro $(p>0.1)$. After $48 \mathrm{~h}$ of culture, the low dose of $\mathrm{LH}$ also increased the concentration of $\mathrm{P} 4 \mathrm{in}$ luteal cultures from ISe- compared to MIX-treated cows $(p<0.05)$. At 72 and $96 \mathrm{~h}$ of culture, there were no differences between dietary treatments in the production of $\mathrm{P} 4$ in response 
to LH or hCG. Furthermore, there was no effect of form of Se on PGE 2 -treated luteal cells throughout the $96 \mathrm{~h}$ of culture ( $p>0.05$, data not shown).

Table 1. Relative abundance of mRNA encoding selenoproteins and selenoprotein P receptors in the CL of cows supplemented with vitamin-mineral mixes containing Se as sodium selenite (ISe, $n=5$ ) or a 1:1 equimolar mix of ISe and OSe (MIX, SEL-PLEX, $n=5)^{1}$.

\begin{tabular}{|c|c|c|c|c|c|}
\hline \multirow{2}{*}{ Gene } & \multirow{2}{*}{ Gene Name } & \multicolumn{4}{|c|}{ qPCR } \\
\hline & & ISe & MIX & SEM & $p$-Value ${ }^{2}$ \\
\hline \multicolumn{6}{|c|}{ Iodothyronine deiodinases } \\
\hline DIO1 & Iodothyronine deiodinase 1 & 1.6668 & 1.3540 & 0.5915 & 0.89 \\
\hline DIO3 & Iodothyronine deiodinase 3 & 1.8881 & 0.7281 & 0.5667 & 0.54 \\
\hline \multicolumn{6}{|c|}{ Glutathione peroxidases } \\
\hline GPX2 & Glutathione peroxidase 2 & 1.1133 & 1.3412 & 0.2026 & 0.45 \\
\hline GPX4 & Glutathione peroxidase 4 & 1.0200 & 0.8963 & 0.0906 & 0.36 \\
\hline \multicolumn{6}{|c|}{ Thioredoxin reductases } \\
\hline TXNRD1 & Thioredoxin reductase 1 & 1.0338 & 1.2380 & 0.1528 & 0.37 \\
\hline TXNRD2 & Thioredoxin reductase 2 & 1.0034 & 1.0816 & 0.0435 & 0.24 \\
\hline TXNRD3 & Thioredoxin reductase 3 & 1.0357 & 1.2130 & 0.1613 & 0.50 \\
\hline \multicolumn{6}{|c|}{ Other selenoproteins } \\
\hline SELENOF & Selenoprotein F & 1.0223 & 0.8537 & 0.0983 & 0.26 \\
\hline SELENOI & Selenoprotein I & 1.0089 & 1.2904 & 0.1215 & 0.14 \\
\hline SELNOK & Selenoprotein $\mathrm{K}$ & 1.0143 & 1.2131 & 0.0810 & 0.12 \\
\hline SELNOM & Selenoprotein $\mathrm{M}$ & 4.6687 & 7.5038 & 2.9960 & 0.52 \\
\hline SELENON & Selenoprotein $\mathrm{N}$ & 1.0196 & 1.0072 & 0.0733 & 0.91 \\
\hline SELENOO & Selenoprotein $\mathrm{O}$ & 1.0234 & 1.1227 & 0.0808 & 0.33 \\
\hline SELENOS & Selenoprotein S & 1.0131 & 1.2860 & 0.1229 & 0.16 \\
\hline SELENOT & Selenoprotein $\mathrm{T}$ & 1.0398 & 0.9553 & 0.1090 & 0.60 \\
\hline SELENOW & Selenoprotein $\mathrm{W}$ & 1.0183 & 1.1465 & 0.1134 & 0.44 \\
\hline SEPHS1 & Selenophosphate synthetase 1 & 1.0655 & 1.6289 & 0.2718 & 0.18 \\
\hline SEPHS2 & Selenophosphate synthetase 2 & 1.0142 & 1.0127 & 0.0738 & 0.99 \\
\hline \multicolumn{6}{|c|}{ Selenoprotein P receptors } \\
\hline$L R P 2$ & LDL receptor related protein 2 & 1.0335 & 1.2207 & 0.1478 & 0.40 \\
\hline$L R P 8$ & LDL receptor related protein 8 & 1.0647 & 1.2923 & 0.1858 & 0.41 \\
\hline TFRC $^{\dagger}$ & Transferrin receptor & $1.0104^{\mathrm{a}}$ & $1.5173^{b}$ & 0.1116 & 0.01 \\
\hline
\end{tabular}

${ }^{1}$ Se was supplemented at $35 \mathrm{ppm}$ as either inorganic (ISe; sodium selenite), or a 1:1 combination (MIX) of ISe and OSe (SEL-PLEX). ${ }^{2} p$-values are associated with Student's $t$-Test. ${ }^{\dagger}$ Means with different superscripted letters differ at $p<0.05$

\subsection{Real-Time PCR Analysis of Steroidogenic and Cholesterol Related mRNA Transcripts}

The relative abundance of 21 mRNA transcripts associated with $\mathrm{P} 4$ biosynthesis and regulation were analyzed via qPCR. Form of Se did not $(p>0.05)$ affect the abundance of the five targeted enzymatic transcripts (Table 3 ). Of the targeted receptor transcripts, the expression of mRNA encoding the nuclear P4 receptor $(P g r)$ was decreased in CL retrieved from MIX versus ISe treated cows $(p<0.05)$. Of the five targeted transcripts associated with cholesterol availability, the level of expression of mRNA encoding both $L d l r$, and $H s l$ was increased in CL retrieved from MIX versus ISe supplemented cows (Figure 6, $p<0.05$ ). 
Table 2. Effect of treatment (form of supplemental Se) on the concentration of systemic P4 in cows between days 4 and 10 of the estrous cycle. Cows were supplemented with Se as sodium selenite (ISe, $n=5$ ) or a 1:1 equimolar mix of ISe and OSe (MIX, SEL-PLEX, $n=5)^{1,+}$

\begin{tabular}{|c|c|c|c|}
\hline \multirow[b]{2}{*}{ Variable } & \multicolumn{2}{|c|}{ Treatment } & \multirow[b]{2}{*}{$p$-Value } \\
\hline & $\begin{array}{c}\text { ISe } \\
\text { LS Mean } \pm \text { SEM }\end{array}$ & $\begin{array}{c}\text { MIX } \\
\text { LS Mean } \pm \text { SEM }\end{array}$ & \\
\hline \multicolumn{4}{|c|}{ Progesterone $(\mathrm{ng} / \mathrm{mL})$ Year 1 * } \\
\hline No. of cows $(n)$ & 9 & 9 & \\
\hline Day $6^{+}$ & $3.44 \pm 0.18^{\mathrm{a}}$ & $5.14 \pm 0.60^{b}$ & 0.035 \\
\hline \multicolumn{4}{|l|}{ Year $2 * *$} \\
\hline No. of cows $(n)$ & 12 & 12 & \\
\hline Day 4 & $1.02 \pm 0.22$ & $0.94 \pm 0.12$ & 0.740 \\
\hline Day $7^{+}$ & $2.92 \pm 0.27^{\mathrm{a}}$ & $3.91 \pm 0.16^{b}$ & 0.006 \\
\hline Day 10 & $7.17 \pm 0.54$ & $6.36 \pm 0.55$ & 0.308 \\
\hline \multicolumn{4}{|l|}{ Year 3} \\
\hline No. of cows $(n)$ & 5 & 5 & \\
\hline Day 5 & $0.59 \pm 0.58$ & $1.20 \pm 0.55$ & 0.456 \\
\hline Day 6 & $0.86 \pm 0.55$ & $1.19 \pm 0.55$ & 0.678 \\
\hline Day 7 & $1.87 \pm 0.55$ & $2.92 \pm 0.55$ & 0.198 \\
\hline CL weight (g) & $6.07 \pm 0.82$ & $6.77 \pm 0.82$ & 0.563 \\
\hline CL diameter (mm) & $22.3 \pm 1.09$ & $23.2 \pm 1.09$ & 0.576 \\
\hline
\end{tabular}

${ }^{1}$ Selenium was supplemented at $35 \mathrm{ppm}$ as either inorganic (ISe; sodium selenite), or a 1:1 combination (MIX) of ISe and OSe (SEL-PLEX). Selenium was supplemented individually using in-pasture Calan gates [26]. ${ }^{2} p$-values associated with one-way ANOVA (year 1, OSe treatment not shown), ANOVA with repeated measures (year 2 and year 3), and Student's $t$-Test (CL weight and CL diameter). ${ }^{\dagger}$ Means with different superscripted letters differ at $p<0.05 .{ }^{*}$ Reported in [33]. ${ }^{* *}$ Reported in [34].

\section{In vitro basal concentration of $\mathrm{P} 4$}

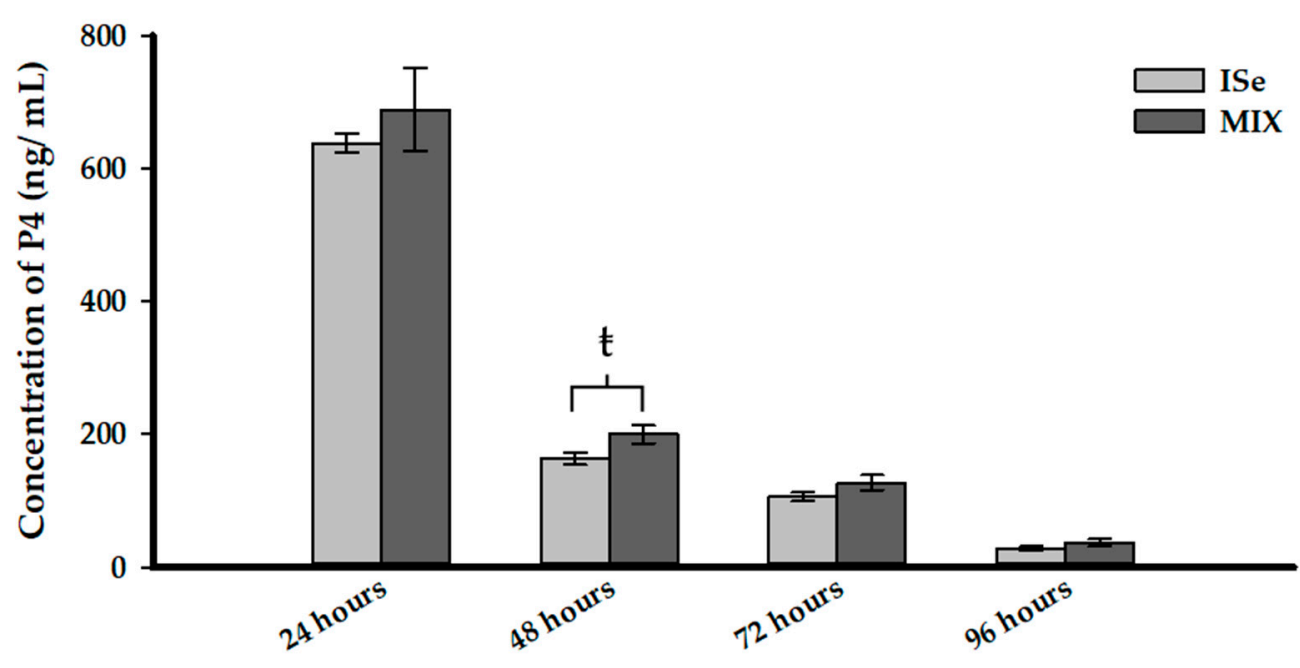

Time in culture

Figure 4. Effect of treatment (form of Se) on basal media concentrations of P4 (ng/mL; LS mean \pm SEM) collected from in vitro culture every $24 \mathrm{~h}$ for $96 \mathrm{~h}$ from cows supplemented with either sodium selenite ISe (sodium selenite; $n=5$ ) or a 1:1 combination (MIX) of ISe and OSe (Sel-Plex; $n=5$ ) treatments. Data were analyzed using a split plot design for repeated measure. Significant differences were determined at $p<0.05$ and tendencies were determined at $0.05 \leq p<0.1$. Tendencies are indicated by $t$. 


\section{A. In vitro concentration of $\mathrm{P} 4$}
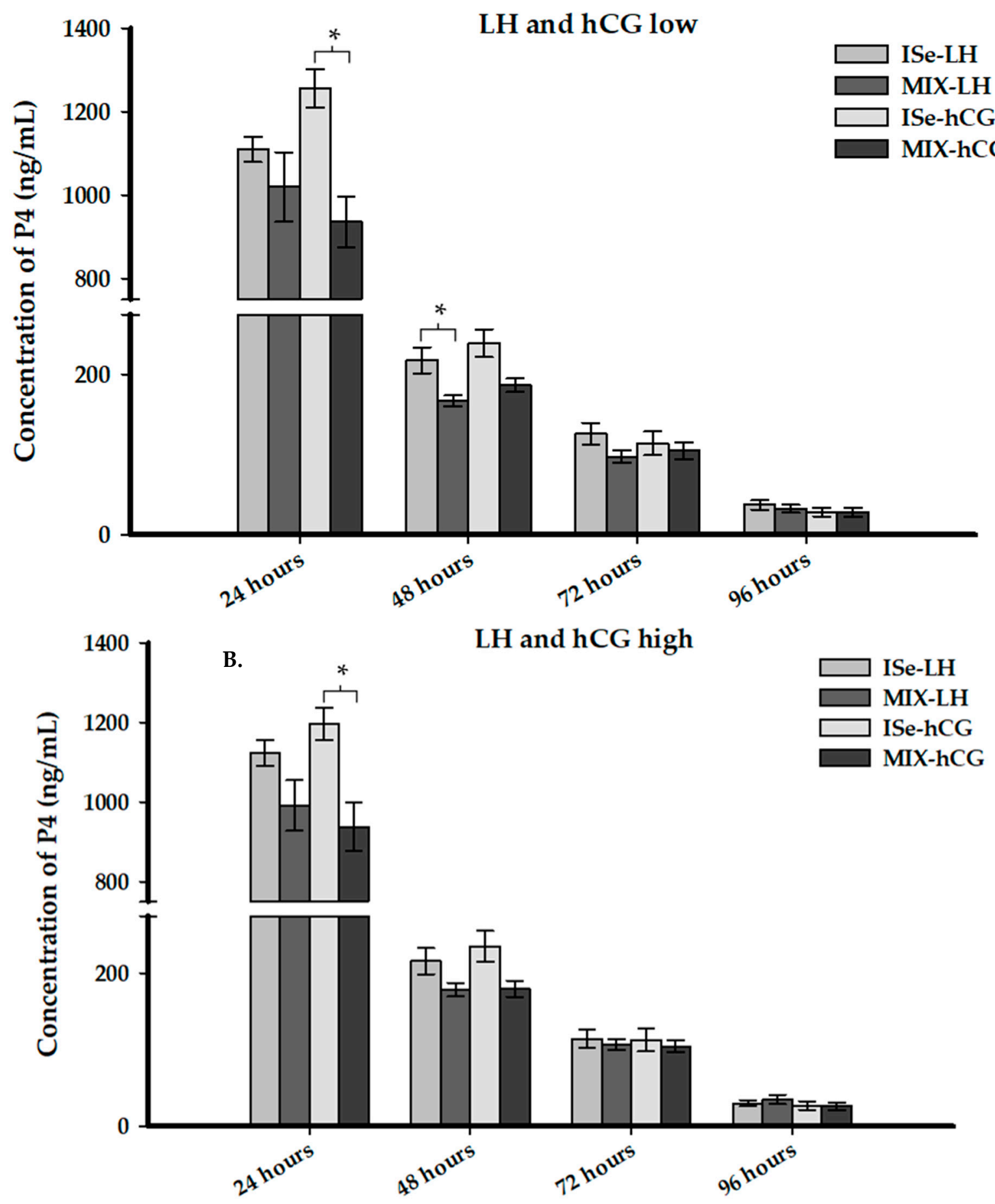

Time in culture

Figure 5. Effect of form of Se on concentrations of P4 in culture media (ng/mL; LS mean \pm standard error of the mean) collected after in vitro culture of dissociated luteal cells with a low (A) or high (B) dose of LH (1 or $10 \mathrm{IU} / \mathrm{mL}$ ) or hCG $(10$ or $50 \mathrm{ng} / \mathrm{mL})$. Corpora lutea were recovered from cows supplemented with either ISe (Sodium selenite; $n=5$ ) or a 1:1 combination (MIX) of ISe and OSe (Sel-Plex; $n=5$ ) on Day 7 post-estrus. Data were analyzed using split plot design for repeated measure. Significant differences were determined at $p<0.05$ and are designated by an asterisk. 
Table 3. Effect of form of Se on the relative expression of mRNA transcripts encoding steroidogenic enzymes and receptors in the Day 7 CL. Cows were supplemented with Se as sodium selenite (ISe, $n=5$ ) or a 1:1 equimolar mix of ISe and OSe (MIX, SEL-PLEX, $n=5)^{1,+}$

\begin{tabular}{|c|c|c|c|c|c|}
\hline \multirow{2}{*}{ Gene } & \multirow{2}{*}{ Gene Name } & \multicolumn{4}{|c|}{ qPCR } \\
\hline & & ISe & MIX & SEM & $p$-Value ${ }^{2}$ \\
\hline \multicolumn{6}{|c|}{ Enzymatic transcripts } \\
\hline STAR & $\begin{array}{l}\text { Steroidogenic acute } \\
\text { regulatory protein } \\
\text { Cytochrome } \mathrm{P} 450 \text {, family }\end{array}$ & 1.0231 & 1.2259 & 0.1132 & 0.2410 \\
\hline CYP11A1 & $\begin{array}{l}\text { 11, subfamily } \mathrm{A} \\
\text { polypeptide } 1\end{array}$ & 1.0068 & 0.9822 & 0.0503 & 0.7371 \\
\hline HSD3B1 & $\begin{array}{l}\text { Hydroxy-delta-5-steroid } \\
\text { dehydrogenase, } 3 \text { beta- } \\
\text { and steroid } \\
\text { delta-isomerase } 1\end{array}$ & 1.0014 & 0.9521 & 0.0398 & 0.4069 \\
\hline PTGS2 & $\begin{array}{l}\text { Prostaglandin- } \\
\text { endoperoxide synthase } 2 \\
\text { (COX2) }\end{array}$ & 1.0079 & 0.9396 & 0.1574 & 0.7668 \\
\hline PTGES & Prostaglandin E synthase & 1.4308 & 0.9376 & 0.3539 & 0.3533 \\
\hline \multicolumn{6}{|c|}{ Receptor transcripts } \\
\hline & Luteinizing hormone (LH) & & & & \\
\hline LHCGR & $\begin{array}{l}\text { G-protein coupled } \\
\text { receptor }\end{array}$ & 1.0484 & 0.6859 & 0.1433 & 0.1112 \\
\hline PGR & $\begin{array}{l}\text { Nuclear progesterone } \\
\text { receptor }\end{array}$ & $1.0076^{\mathrm{a}}$ & $0.8415^{b}$ & 0.0508 & 0.0495 \\
\hline PGRMC1 & $\begin{array}{l}\text { Progesterone receptor } \\
\text { membrane component } 1\end{array}$ & 1.0355 & 0.9044 & 0.1060 & 0.4071 \\
\hline PGRMC2 & $\begin{array}{l}\text { Progesterone receptor } \\
\text { membrane component } 2\end{array}$ & 1.0248 & 1.0553 & 0.0970 & 0.8295 \\
\hline EP1 & Prostaglandin E receptor 1 & 1.2310 & 1.4844 & 0.0721 & 0.5832 \\
\hline$E P 2$ & Prostaglandin E receptor 2 & 1.0385 & 1.0890 & 0.1392 & 0.8041 \\
\hline EP3 & Prostaglandin E receptor 3 & 1.0286 & 0.7820 & 0.1045 & 0.1337 \\
\hline EP4 & $\begin{array}{l}\text { Prostaglandin E receptor } 4 \\
\text { Progestin and adipoQ }\end{array}$ & 1.0313 & 1.2515 & 0.1524 & 0.3368 \\
\hline PAQR5 & $\begin{array}{l}\text { receptor family member } 5 \\
(\mathrm{mPR} \gamma)\end{array}$ & 1.0342 & 0.9295 & 0.1187 & 0.5502 \\
\hline PAQR7 & $\begin{array}{l}\text { Progestin and adipoQ } \\
\text { receptor family member } 7 \\
(\mathrm{mPR} \alpha)\end{array}$ & 1.0165 & 0.8922 & 0.0804 & 0.3058 \\
\hline PAQR8 & $\begin{array}{l}\text { Progestin and adipoQ } \\
\text { receptor family member } 8 \\
(\mathrm{mPR} \beta)\end{array}$ & 1.0042 & 1.0206 & 0.0678 & 0.8687 \\
\hline PGTFR & Prostaglandin F receptor & 1.0493 & 0.8624 & 0.1735 & 0.4680 \\
\hline
\end{tabular}

${ }^{1}$ Selenium was supplemented at $35 \mathrm{ppm}$ as either inorganic (ISe; sodium selenite), or a 1:1 combination (MIX) of ISe and OSe (SEL-PLEX). Selenium was supplemented individually using in-pasture Calan gates [26]. ${ }^{2} p$-values associated with Student's $t$-Test. ${ }^{\dagger}$ Means with different superscripted letters differ $(p<0.05)$. 


\section{Relative concentration of mRNA transcripts associated with cholesterol availability}

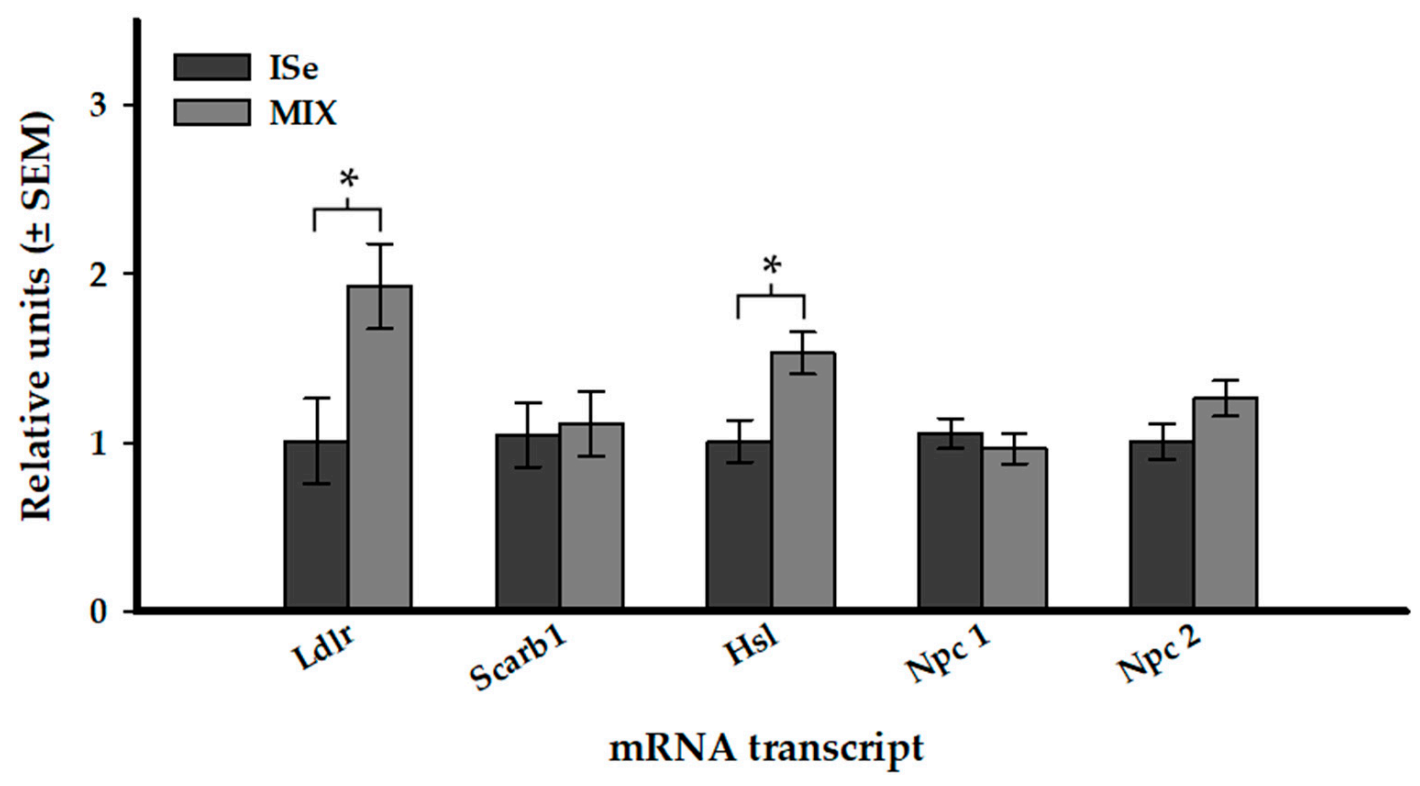

Figure 6. Effect of form of Se on the expression of mRNA transcripts associated with the availability of cholesterol in the CL of cows supplemented with Se in vitamin mineral mixes as ISe (sodium selenite; $n=5$ ) or a 1:1 combination (MIX) of ISe and OSe (Sel-Plex; $n=5$ ). $p$-values are associated with Student's $t$-test. Significant differences at $p<0.05$ are indicated by an asterisk.

\section{Discussion}

In this study, we sought to investigate the mechanism responsible for increases in early luteal phase concentrations of peripheral $\mathrm{P} 4$ after supplementation with MIX versus the industry standard ISe [33,34]. The specified objectives were to investigate the effect of supplementation with ISe or MIX-form Se on (1) the relative abundance of mRNA transcripts that encode selenoproteins and targeted steroidogenic enzymes in the CL, and (2) the ability of dissociated luteal cells to synthesize P4 in response to key agonists in vitro. We first verified our model by demonstrating the diets containing distinct Se-form specific vitamin-mineral mixes resulted in a selenium-adequate status in all animals during experimentation $[24,39,40]$. Further, we analyzed serum concentrations of P4 collected from cows on Days 5 to 7 of the early luteal phase to model the previously defined MIX-induced increase in P4. Our previous studies reported a $1.7 \mathrm{ng} / \mathrm{mL}$ increase in Day 6 (year one) concentrations of P4 [33], and a $1.0 \mathrm{ng} / \mathrm{mL}$ increase in Day 7 (year 2) P4 [34]. In the present study, we mimicked this difference with a $1.1 \mathrm{ng} / \mathrm{mL}$ increase in P4 on day 7 of the estrous cycle in the MIX treatment group. Although this difference was not statistically significant, we suspect that the lack of an effect in the serum concentration of P4 may be due to (1) the smaller number of animals in this more intensive study, and/or (2) a possible dietary interaction because our previous studies were performed using cattle maintained on toxic endophyte-infected tall fescue pastures, versus the study herein where cattle grazed novel, nontoxic endophyte-infected tall fescue pastures, followed by a silage-based diet over the winter months of January to April. Importantly, in both Cerny, et al. [33] and the current study, this increase in peripheral concentrations of P4 occurred in the absence of any treatment effect on weight or diameter of the CL, suggesting increased capacity of individual steroidogenic cells to synthesize P4.

Regarding selenoproteins, the physiological incorporation of Se into any tissue is dependent upon the form available [6]. SeMet enters the methionine metabolic pool and readily competes with Met for incorporation into protein by tRNA. The amount of incorporation of SeMet compared to methionine is dependent on their relative concentrations [56]. 
Alternatively, SeMet can be converted to SeCys via the intermediate selenocystathionine and the enzymatic activity of both cystathionine B-synthase and cystathionine [6,57]. The synthesized SeCys or dietary SeCys is transformed into selenide by $\beta$-lyase activity [6]. Contrary to the organic forms of Se, once consumed, selenate is easily converted to selenite and then further converted to selenide [57]. The formation of selenide is where the metabolic pathways for organic and inorganic forms of Se converge. Selenide is converted to the intermediate selenophosphate by the known selenoprotein enzymes selenophosphate synthetases (SEPHS1 and SEPHS2) [58,59]. Selenophosphate then interacts with a charged serine present on the specific ${ }^{S e C y s}$ tRNA, followed by the conversion of Ser-SeCys ${ }^{2}$ RNA to SeCys- ${ }^{S e C y s}$ tRNA for incorporation into selenoproteins $[6,60]$.

In the CL, ROS including hydrogen peroxide and hydroxyl radicals are produced as a byproduct of aerobic metabolism when the P450/450 system catalyzes the reaction to produce P4 [61,62]. Similarly to what occurs in other cell types, ROS are also generated in the luteal cells during the production of ATP from oxidative phosphorylation by the oxidase NADH and NADPH, and by the activity of xanthine oxidase [63,64]. Therefore, antioxidants must be active to regulate the concentration of ROS and maintain cellular viability, as the concentration of ROS and antioxidants are closely related to luteal function [65-69]. Intra-luteal concentrations of ROS can be inhibitory to the production of P4 during luteolysis and pregnancy in rats $[70,71]$. Hence, maintenance of cellular function and production of $\mathrm{P} 4$ requires the regulation of concentrations of ROS by antioxidants. Unregulated ROS or increases in intracellular concentrations of ROS have been associated with apoptosis of the steroidogenic cells and luteolysis of the CL [72-75].

GPX variants are known to reduce hydrogen peroxide [9] and relevant to the current study, we observed a significant increase in the abundance of mRNA encoding Gpx6 and a tendency of increasing Gpx1 and Gpx3 mRNA content in the CL from MIX supplemented cows. The most abundant glutathione peroxidase is the cytosolic GPX1. Vu, et al. [72] demonstrated that GPX1 protein abundance and activity is greatest in the early and midluteal stages aligning with the increases in the production of $\mathrm{P} 4$ at this time. In contrast, we did not observe any difference in the mitochondrial GPX4 which has the ability to alleviate apoptogenic protein release on the inner membrane of the mitochondria [76]. The roles of the GPX3 and GPX6 are not clearly defined in the CL, although we speculate that they exert a similar function related to reducing ROS. GPX3 is most highly abundant in blood [77], and previously researchers have demonstrated that the mRNA encoding Gpx6 has been located in limited tissues including embryos, olfactory epithelium, sperm, seminal plasma, and the ovaries in humans [77-82]. The present study provides novel evidence of the presence and role for GPX6 in the CL of cows, and that the Gpx6 mRNA abundance is significantly affected by the form of Se, with mRNA encoding Gpx6 being increased in the CL from cows in the MIX treatment group. Other selenoproteins with antioxidant capabilities, and in which we observed a significant effect or tendency to increase abundance in the MIX treatment group of the respective mRNA transcripts encoding Selenop [14], Selenoh [16], and Selenor [19]. Of note, SELENOP has redox capabilities; however, its main physiological function is to maintain homeostasis of the concentration of Se [83]. It is primarily synthesized in the liver and transported through the plasma to target tissues to be internalized in the cell by receptor-mediated endocytosis [83]. Hence, it is of interest that the mRNA encoding Selenop was significantly upregulated in MIX treated cows, although the relevance within the CL is unclear at this time.

Of equal importance to the current study, systemic P4 is affected by a plethora of factors, including the rate of P4 synthesis in the CL, the rate of catabolism in the liver, and various luteotropic and luteolytic hormones [84-89]. In the cow, LH is considered the primary luteotropic hormone. In vitro stimulation of luteal cells with LH can increase the production of P4 by up to 20 -fold $[85,86]$. The small steroidogenic cells of the CL contain receptors for LH (luteinizing hormone G-protein coupled receptor, LHCGR) which can assert its effects by acting through the protein kinase A (PKA) second messenger system to stimulate production of $\mathrm{P} 4[85,86]$. However, large steroidogenic luteal cells that contribute 
a 20-fold greater amount of the P4 per cell are devoid of the LH receptor; thus, they do not respond to simulation by that gonadotropic hormone [86,90]. In the present study, we unexpectedly observed minor ISe-induced increases in P4 after treatment of luteal cells with LH or hCG in vitro, with hCG stimulating the small luteal cell similarly to LH [91]. Considering the relative level of expression of mRNA encoding the LH/hCG receptor (1.05 vs. $0.69 \pm 0.14$, ISe vs. MIX, relative units $\pm \mathrm{SEM}, p=0.11$ ) that we observed in luteal tissue herein, a form of Se-induced effect on small luteal cell steroidogenesis may be apparent.

Large luteal cells contain receptors, including those for $\mathrm{PGE}_{2}$ and $\mathrm{PGF}_{2 \alpha}[86,87] . \mathrm{PGE}_{2}$ has a luteotropic and luteoprotective role in the $\mathrm{CL}$ and $\mathrm{PGF}_{2 \alpha}$ is luteolytic [86,87]. In ruminants, treating luteal cells with $\mathrm{PGE}_{2}$ has resulted in an increase in the production of P4 [92-94], increased protection of the CL from luteolysis [95-98], and stimulation of the secretion of P4 by binding to the prostaglandin E receptors 1-4 (EP1, EP2, EP3, and EP4) on the plasma membrane and activation of the cAMP-mediated signaling pathway $[88,89]$. We did not observe an effect of treatment with $\mathrm{PGE}_{2}$ on luteal cell-production of $\mathrm{P} 4$ in the study, nor an effect of form of Se on the expression of mRNA encoding the Ep1-4 receptors.

Intuitively, there is no clear connection between feeding a MIX Se-form supplement and the observed increases in systemic concentrations of P4. Therefore, to investigate this mechanism, we first analyzed for differences in the expression of transcripts for key steroidogenic enzymes and associated receptors. We hypothesized that there would be an increase in enzymatic transcripts and receptor transcripts that favor the production of P4. Our initial hypothesis was not substantiated. Interestingly, among the transcripts analyzed, the content of mRNA encoding the nuclear Pgr but not the membrane components Pgrmc1 and Pgrmc2 was decreased in CL from MIX-supplemented cows suggesting downregulation of PGR mediated events in those animals. Both on and within steroidogenic luteal cells, $\mathrm{P} 4$ auto-regulates the further production of $\mathrm{P} 4$ by binding to either the nuclear membrane receptors (PGR-A and PGR-B), or the cytoplasmic and endoplasmic membrane bound P4 receptors, P4 receptor membrane components 1 and 2 (PGRMC1 and PGRMC2, respectively). $\mathrm{P} 4$ also binds the progestin and adipoQ receptor family members 5,7 , and 8 (PAQR5, PAQR7, and PAQR8, respectively) [99,100].

After analyzing the results of transcripts related to the production of P4, concurrent with the results from our in vitro study, it was clear that the regulatory activity of the peripheral production of $\mathrm{P} 4$ had to be either upstream or downstream of the targeted steroidogenic pathway (Figure 7). Mechanistically, the primary substrate for the production of $\mathrm{P} 4$ is cholesterol, which is made available to steroidogenic luteal cells via four mechanisms: conversion of low-density lipoproteins (LDL), uptake of high-density lipoproteins (HDL), the uptake of free cholesterol, or de novo synthesis [101-103]. The conversion of LDL and HDL into free cholesterol is the prominent pathway to make this substrate available for the production of P4 in the CL [104-106]. The uptake of LDL occurs by binding to the LDL receptor (LDLR) and triggering receptor mediated endocytosis [107]. The endosome containing the LDL combines with lysosomes and LDL is dissociated from the receptor to be broken down into free cholesterol [108]. Transport out of the lysosome occurs by binding the cholesterol transporters: Niemann-Pick C1 protein (NPC1) and NiemannPick C2 protein [NPC2 [109-111]]. LDL-derived free cholesterol is rapidly exported out of the lysosomal compartments via the actions of NPC1 and NPC2, and without these transporters, cholesterol and other lipids would accrete within the lysosomes [112]. In contrast, HDL is utilized as a substrate for cholesterol by first binding to the scavenger receptor class B type 1 (SCARB1) on the cell surface. The lipoprotein is not entirely internalized; rather, the cholesteryl esters are selectively delivered into the cell to be hydrolyzed into free cholesterol [113-115]. Another mechanism relevant to the present study and associated with the availability of P4 in steroidogenic cells is the hydrolysis of cholesteryl esters to free cholesterol from lipid droplets. This reaction is stimulated by hormone-sensitive lipase (HSL) which results in free cholesterol and fatty acids that can then act as precursors for various physiological functions, including the production of steroid hormones and cellular energy [116-120]. 


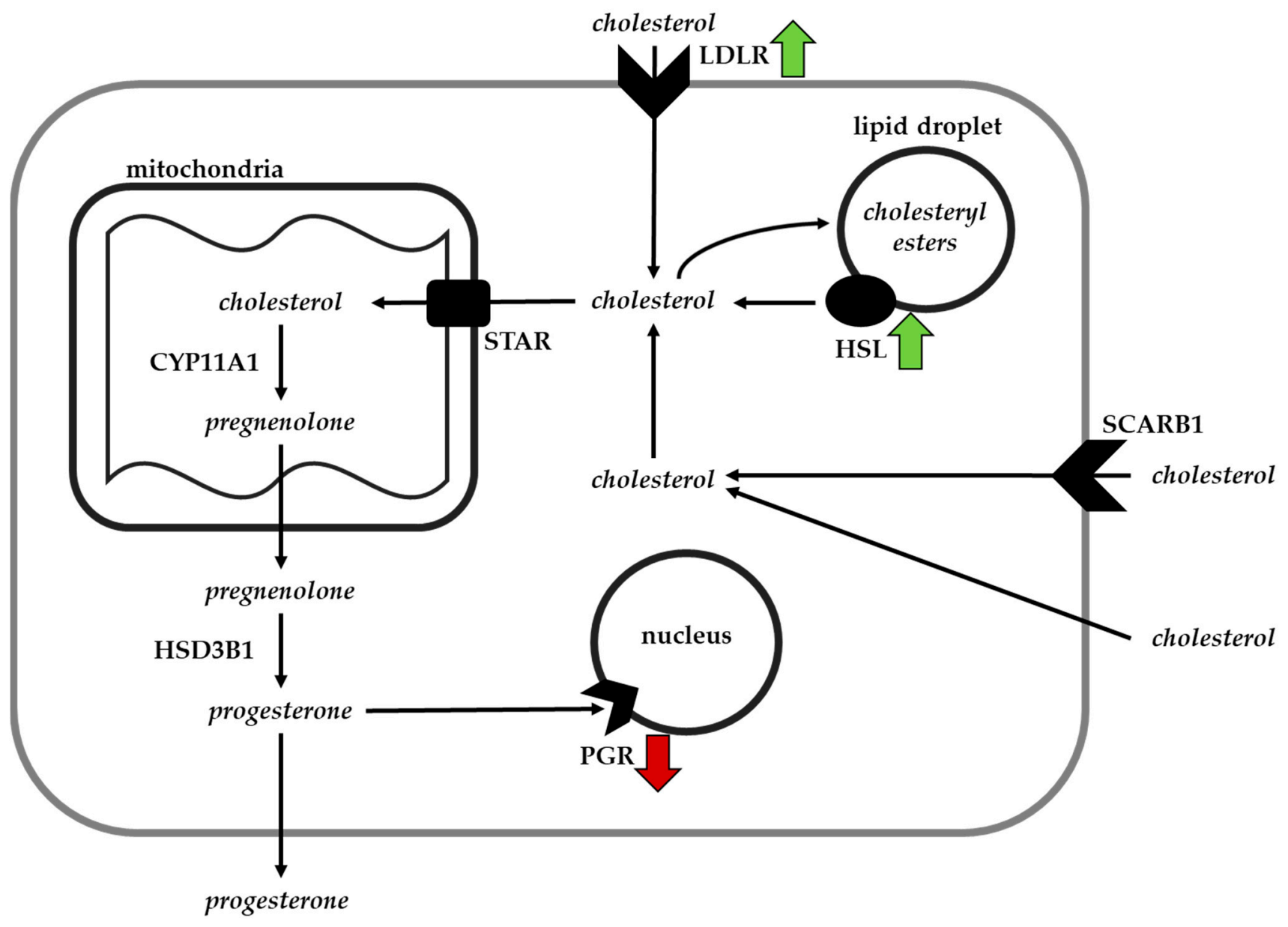

Figure 7. Mechanism of the availability of cholesterol and steroidogenesis in a steroidogenic luteal cell, emphasizing the four potential sources of cholesterol that are available as a substrate. Each arrow represents a significant difference in the abundance of mRNA associated with each respective protein. The arrow pointing upward or downward indicates that the mRNA is significantly upregulated (green) or downregulated (red) respectively in the MIX treatment group compared to the ISe treatment group.

Once cholesterol is free, it is transported into the mitochondria by binding the steroidogenic acute regulatory protein (STAR), which then interactions with membrane proteins on both the outer and inner mitochondrial membranes to facilitate the transport into the inner mitochondrial matrix [121]. This mechanism mediates the rate at which P4 can be produced [122-124]. Cholesterol is then converted into pregnenolone via the actions of cytochrome P450 family 11 member1 (CYP11A1) located on the inner mitochondrial membrane [125-128]. Once transported out of the mitochondria, the enzymes hydroxydelta-5-steroid dehydrogenase, 3 beta- and steroid delta isomerase 1 (HSD3B1) located in the endoplasmic reticulum further converts pregnenolone into P4 [129] allowing autocrine, paracrine, and endocrine activity of the hormone.

We targeted five transcripts ( $L d l, S c a r b 1, N p c 1, N p c 2$, and $H s l)$ that are indicative of the availability of cholesterol to steroidogenic cells. Of these, transcripts encoding $\mathrm{Ldlr}$ and Hsl were significantly upregulated in the MIX Se treatment group suggesting that the MIXinduced increase in in vivo P4 is due, in part, to stimulation of cholesterol uptake. Since we observed increases in mRNA encoding the Ldlr transcript in the MIX-supplemented Day $7 \mathrm{CL}$, the failure to observe a MIX-induced increase in the production of P4 in vitro appears to be due to the fact that there is limited cholesterol available in the serum-free media for the cells to internalize as substrate. Thus, these cells cannot recapitulate the 
in vivo increase in the production of P4 by the CL from cows supplemented with the MIX form of Se.

Given this, the mechanism between dietary form of Se and the MIX-induced increase in early luteal phase P4 requires further research to define. However, it appears that it could partially be due to differences in the physiological integration of both selenoproteins and cholesterol, with cholesterol being the primary substrate for the production of P4 by the CL. Selenium is an integral component of GPX enzymes, which have antioxidant activity by removing hydrogen peroxide and protecting against the aggregation of reactive oxygen species (ROS). We have previously demonstrated that feeding the MIX form or the organic form of Se significantly upregulates the Gpx4 transcript in the pituitary of steers when compared to ISe [22], which asserts antioxidant properties there. ROS are generated in the mitochondria of the CL and have been shown to reduce the production of P4 [71,130-133]. Additionally, ROS damage LH receptors [133,134], inhibit the transfer of cholesterol to the mitochondria for the synthesis of P4 [131], and inhibit the enzymatic activity of P450scc [132]. In concert, the information discussed herein provides a plausible mechanism for the association between supplementing the MIX Se-form and increased production of $\mathrm{P} 4$. However, additional research that analyzes transcripts associated with cholesterol biosynthesis and the production of ROS within the CL, are warranted to further define the interrelationships between the form of dietary Se, systemic concentrations of cholesterol, and peripheral concentrations of $\mathrm{P} 4$.

\section{Conclusions}

In this study, we sought to quantify Se form-induced changes in the expression of mRNA encoding selenoproteins and to investigate the mechanism(s) responsible for the previously reported increase in early luteal phase concentrations of $\mathrm{P} 4$ in cows supplemented with the MIX form of Se. Though the mechanism is still not completely defined, we have demonstrated that the form of selenium does not affect steroidogenic enzyme mRNA expression but does alter mRNA transcripts associated with the availability of cholesterol to steroidogenic luteal cells. Further research is necessary to determine how the bioavailability of cholesterol is affected. Overall, it appears that the MIX-induced increase in early luteal P4 is not directly mediated by an increase in the key steroidogenic transcripts but by an increase in cholesterol uptake, through at least the LDLR. Understanding the mechanism of the MIX-induced increase in P4 is requisite, as this novel dietary approach offers a producer-friendly avenue to increase fertility outcomes in beef cows grazing forages in areas with soils deficient in Se.

Supplementary Materials: The following are available online at https:/ /www.mdpi.com/article/10 .3390/ani12030313/s1, Table S1: Primer sets and product identities of qPCR analysis of selenoproteinassociated genes, Table S2: Primer sets and product identities of qPCR analysis of reference and steroidogenesis-associated genes.

Author Contributions: Conceptualization and methodology, P.J.B.; funding acquisition P.J.B. and J.C.M.; project administration, P.J.B.; investigation, P.J.B., S.N.C., B.R.C., J.L.P., C.H.K.H. and J.C.M.; writing—original draft preparation, S.N.C.; writing—review and editing, P.J.B., J.C.M. and J.L.P. All authors have read and agreed to the published version of the manuscript.

Funding: This project was funded by Agriculture and Food Research Initiative Competitive Grant no. 2018-67015-27613 from the USDA National Institute of Food and Agriculture (P.J.B., J.C.M.).

Institutional Review Board Statement: This study was approved by the University of Kentucky's Institutional Animal Care and Use Committee (IACUC), protocol number 2017-2828.

Informed Consent Statement: Not applicable.

Data Availability Statement: Not applicable.

Acknowledgments: The authors thank the faculty and farm crew at the University of Kentucky Research and Education center at Princeton, KY for their dedicated work in maintaining the cattle used herein. 
Conflicts of Interest: The authors declare no conflict of interest.

\section{References}

1. $\quad$ Gleed, P.T.; Allen, W.M.; Mallinson, C.B.; Rowlands, G.J.; Sansom, B.F.; Vagg, M.J.; Caswell, R.D. Effects of selenium and copper supplementation on the growth of beef steers. Vet. Rec. 1983, 113, 388-392. [CrossRef] [PubMed]

2. Erskine, R.J.; Eberhart, R.J.; Grasso, P.J.; Scholz, R.W. Induction of Escherichia coli mastitis in cows fed selenium-deficient or selenium-supplemented diets. Am. J. Vet. Res. 1989, 50, 2093-2100.

3. Boyne, R.; Arthur, J.R. Alterations of neutrophil function in selenium-deficient cattle. J. Comp. Pathol. 1979, 89, 151-158. [CrossRef]

4. McClure, T.J.; Eamens, G.J.; Healy, P.J. Improved fertility in dairy cows after treatment with selenium pellets. Aust. Vet. J. 1986, 63, 144-146. [CrossRef] [PubMed]

5. Enjalbert, F.; Lebreton, P.; Salat, O. Effects of copper, zinc and selenium status on performance and health in commercial dairy and beef herds: Retrospective study. J. Anim. Physiol. Anim. Nutr. 2006, 90, 459-466. [CrossRef] [PubMed]

6. Suzuki, K.T. Metabolomics of selenium: Se metabolites based on speciation studies. J. Health Sci. 2005, 51, 107-114. [CrossRef]

7. Ammerman, C.B.; Miller, S.M. Selenium in ruminant nutrition: A review. J. Dairy Sci. 1975, 58, 1561-1577. [CrossRef]

8. Flohe, L.; Günzler, W.A.; Schock, H.H. Glutathione peroxidase: A selenoenzyme. FEBS Lett. 1973, 32, 132-134. [CrossRef]

9. Labunskyy, D.M.; Hatfield, D.L.; Gladyshev, V.N. Selenoproteins: Molecular pathways and physiological roles. Physiol. Rev. 2014, 94, 739-777. [CrossRef]

10. Chen, X.D.; Zhao, Z.P.; Zhao, J.C.; Lei, X.G. Evolution, regulation, and function of porcine selenogenome. Free Radic. Biol. Med. 2018, 127, 116-123. [CrossRef]

11. Arnér, E.S.J. Focus on mammalian thioredoxin reductases-important selenoproteins with versatile functions. Biochem. Biophys. Acta 2009, 1790, 495-526. [CrossRef] [PubMed]

12. Rundlöf, A.K.; Carlsten, M.; Arnér, E.S. The core promoter of human thioredoxin reductase 1: Cloning, transcriptional activity and Oct-1, Sp1 and Sp3 binding reveal a housekeeping-type promoter for the AU-rich regulated gene. J. Biol. Chem. 2001, 276, 30542-30551. [CrossRef] [PubMed]

13. Lillig, C.H.; Holmgren, A. Thioredoxin and related molecules-from biology to health and disease. Antioxid. Redox Signal. 2007, 9 , 25-47. [CrossRef]

14. Takebe, G.; Yarimizu, J.; Saito, Y.; Hayashi, T.; Nakamura, H.; Yodoi, J.; Nagasawa, S.; Takahashi, K. A comparative study on the hydroperoxide and thiol specificity of the glutathione peroxidase family and selenoprotein P. J. Biol. Chem. 2002, 277, 41254-41258. [CrossRef] [PubMed]

15. Beilstein, M.A.; Vendeland, S.C.; Barofsky, E.; Jensen, O.N.; Whanger, P.D. Selenoprotein W of rat muscle binds glutathione and an unknown small molecular weight moiety. J. Inorg. Biochem. 1996, 61, 117-124. [CrossRef]

16. Novoselov, S.V.; Kryukov, G.V.; Xu, X.M.; Carlson, B.A.; Hatfield, D.L.; Gladyshev, V.N. Selenoprotein H is a nucleolar thioredoxinlike protein with a unique expression pattern. J. Biol. Chem. 2007, 282, 11960-11968. [CrossRef]

17. Lu, C.; Qiu, F.; Zhou, H.; Peng, Y.; Hao, W.; Xu, J.; Yuan, J.; Wang, S.; Qiang, B.; Xu, C.; et al. Identification and characterization of selenoprotein K: An antioxidant in cardiomyocytes. FEBS Lett. 2006, 580, 5189-5197. [CrossRef]

18. Reeves, M.A.; Bellinger, F.P.; Berry, M.J. The neuroprotective functions of selenoprotein M and its role in cytosolic calcium regulation. Antioxid. Redox Signal 2010, 12, 809-818. [CrossRef]

19. Kryukov, G.V.; Kumar, R.A.; Koc, A.; Sun, Z.; Gladyshev, V.N. Selenoprotein R is a zinc-containing stereo-specific methionine sulfoxide reductase. Proc. Natl. Acad. Sci. USA 2002, 99, 4245-4250. [CrossRef]

20. Matthews, J.C.; Zhang, Z.; Patterson, J.D.; Bridges, P.J.; Stromberg, A.J.; Boling, J.A. Hepatic transcriptome profiles differ among maturing beef heifers supplemented with inorganic, organic, or mixed (50\% inorganic: $50 \%$ organic) forms of dietary selenium Biol. Trace Elem. Res. 2014, 160, 321-339. [CrossRef]

21. Cerny, K.; Garbacik, S.; Skees, C.; Burris, W.; Matthews, J.; Bridges, P. Gestational form of selenium in free-choice mineral mixes affects transcriptome profiles of the neonatal calf testis, Including those of steroidogenic and spermatogenic pathways. Biol. Trace Elem. Res. 2016, 169, 56-68. [CrossRef] [PubMed]

22. Li, Q.; Jia, Y.; Burris, W.R.; Bridges, P.J.; Matthews, J.C. Forms of selenium in vitamin-mineral mixes differentially affect the expression of genes responsible for prolactin, ACTH, and alpha-MSH synthesis and mitochondrial dysfunction in pituitaries of steers grazing endophyte-infected tall fescue. J. Anim. Sci. 2019, 97, 631-643. [CrossRef] [PubMed]

23. Liao, S.F.; Brown, K.R.; Stromberg, A.J.; Burris, W.R.; Boling, J.A.; Matthews, J.C. Dietary supplementation of selenium in inorganic and organic forms differentially and commonly alters blood and liver selenium concentrations and liver gene expression profiles of growing beef heifers. Biol. Trace Elem. Res. 2011, 140, 151-169. [CrossRef] [PubMed]

24. Brennen, K.M.; Burris, W.R.; Boling, J.A.; Matthews, J.C. Selenium content in blood fractions and liver of beef heifers is greater with a mix of inorganic/organic or organic versus inorganic supplemental selenium but the time required for maximal assimilation is tissue-specific. Biol. Trace Elem. Res. 2011, 144, 504-516. [CrossRef]

25. Slavik, P.; Illek, J.; Brix, M.; Hlavicova, J.; Rajmon, R.; Jilek, F. Influence of organic versus inorganic dietary selenium supplementation on the concentration of selenium in colostrum, milk and blood of beef cows. Acta Vet. Scand. 2008, 50, 43. [CrossRef] 
26. Patterson, J.D.; Burris, W.R.; Boling, J.A.; Matthews, J.C. Individual intake of free-choice mineral mix by grazing beef cows may be less than typical formulation assumptions and form of selenium in mineral mix affects blood Se concentrations of cows and their suckling calves. Biol. Trace Elem. Res. 2013, 155, 38-48. [CrossRef]

27. Pehrson, B.; Ortman, K.; Madjid, N.; Trafikowska, U. The influence of dietary selenium as selenium yeast or sodium selenite on the concentration of selenium in the milk of suckler cows and on the selenium status of their calves. J. Anim. Sci. 1999, 77, 3371-3376. [CrossRef]

28. Gunter, S.A.; Beck, P.A.; Phillips, J.M. Effects of supplementary selenium source on the performance and blood measurements in beef cows and their calves. J. Anim. Sci. 2003, 81, 856-864. [CrossRef]

29. Gunter, S.A.; Beck, P.A.; Hallford, D.M. Effects of supplementary selenium source on the blood parameters in beef cows and their nursing calves. Biol. Trace Elem. Res. 2013, 152, 204-211. [CrossRef]

30. Muñiz-Naveiro, Ó.; Domínguez-González, R.; Bermejo-Barrera, A.; Bermejo-Barrera, P.; Cocho, J.A.; Fraga, J.M. Study of the bioavailability of selenium in cows' milk after a supplementation of cow feed with different forms of selenium. Anal. Biol. Chem. 2006, 385, 189-196. [CrossRef]

31. Givens, D.I.; Allison, R.; Cottrill, B.; Blake, J.S. Enhancing the selenium content of bovine milk through alteration of the form and concentration of selenium in the diet of the dairy cow. J. Sci. Food. Agric. 2004, 84, 811-817. [CrossRef]

32. Ceballos, A.; Sánchez, J.; Stryhn, H.; Montgomery, J.B.; Barkema, H.W.; Wichtel, J.J. Meta-analysis of the effect of oral selenium supplementation on milk selenium concentration in cattle. J. Dairy Sci. 2009, 92, 324-342. [CrossRef] [PubMed]

33. Cerny, K.L.; Anderson, L.; Burris, W.R.; Rhoads, M.; Matthews, J.C.; Bridges, P.J. Form of supplemental selenium fed to cycling cows affects systemic concentrations of progesterone but not those of estradiol. Theriogenology 2016, 85, 800-806. [CrossRef] [PubMed]

34. Carr, S.N.; Jia, Y.; Crites, B.R.; Hamilton, C.H.; Burris, W.R.; Edwards, J.L.; Matthews, J.C.; Bridges, P.J. Form of supplemental selenium in vitamin-mineral premixes differentially affects early luteal and gestational concentrations of progesterone, and postpartum concentrations of prolactin in beef cows. Animals 2020, 10, 967. [CrossRef] [PubMed]

35. Forde, N.; Carter, F.; Fair, T.; Crowe, M.A.; Evans, A.C.O.; Spencer, T.E.; Bazer, F.W.; McBride, R.; Boland, M.P.; O'Gaora, P.; et al Progesterone-regulated changes in endometrial gene expression contribute to advanced conceptus development in cattle. Biol. Reprod. 2009, 81, 784-794. [CrossRef]

36. Carter, F.; Forde, N.; Duffy, P.; Wade, M.; Fair, T.; Crowe, M.A.; Evans, A.C.O.; Kenny, D.A.; Roche, J.F.; Lonergan, P. Effect of increasing progesterone concentration from Day 3 of pregnancy on subsequent embryo survival and development in beef heifers. Reprod. Fertil. Dev. 2008, 20, 368-375. [CrossRef]

37. Garrett, J.E.; Geisert, R.D.; Zavy, M.T.; Morgan, G.L. Evidence for maternal regulation of early conceptus growth and development in beef cattle. J. Reprod. Fert. 1988, 84, 437-446. [CrossRef]

38. Wiltbank, M.C.; Souza, A.H.; Carvalho, P.D.; Bender, R.W.; Nascimento, A.B. Improving fertility to timed artificial insemination by manipulation of circulating progesterone concentrations in lactating dairy cattle. Reprod. Fertil. Dev. 2012, 24, 238-243. [CrossRef]

39. Gerloff, B.J. Effect of selenium supplementation on dairy cattle. J. Anim. Sci. 1992, 70, 3934-3940. [CrossRef]

40. Dargatz, D.A.; Ross, P.F. Blood selenium concentrations in cows and heifers on 253 cow-calf operations in 18 states. J. Anim. Sci. 1996, 74, 2891-2895. [CrossRef]

41. National Academies of Sciences, Engineering, and Medicine. Nutrient Requirements of Beef Cattle: Eighth Revised Edition; The National Academies Press: Washington, DC, USA, 2016

42. Kubota, J.; Allaway, W.H. Geographic distribution of trace element problems. In Micronutrients in Agriculture; Mortvedt, J.J., Lindsay, W.L., Giordano, P.M., Eds.; Soil Science Society of America: Madison, WI, USA, 1972; pp. 525-554.

43. Hatler, T.B.; Hayes, S.H.; Ray, D.L.; Reames, P.S.; Silvia, W.J. Effect of subluteal concentrations of progesterone on luteinizing hormone and ovulation in lactating dairy cows. Vet. J. 2008, 177, 360-368. [CrossRef] [PubMed]

44. Pate, J.L. Isolation and culture of fully differentiated bovie luteal cells. Methods Toxicol. 1993, 3B, 360-370.

45. Poole, D.H.; Ndiaya, K.; Pate, J.L. Expression and regulation of secreted phosphoprotein 1 in the bovine corpus luteum and effects on T lymphocyte chemotaxis. Reproduction 2013, 146, 527-537. [CrossRef] [PubMed]

46. Roy, L.; McDonald, C.A.; Jiang, C.; Maroni, D.; Zeleznik, A.J.; Wyatt, T.A.; Hou, X.; Davis, J.S. Convergence of $3^{\prime}, 5^{\prime}$-cyclic adenosine $5^{\prime}$-monophosphate/protein kinase A and glycogen synthase kinase-beta/beta-catenin signaling in corpus luteum progesterone synthesis. Endocrinology 2009, 150, 5036-5045. [CrossRef] [PubMed]

47. Szóstek, A.Z.; Lukasik, K.; Majewska, M.; Bah, M.M.; Znaniecki, R.; Okuda, K.; Skarzynski, D.J. Tumor necrosis factor- $\alpha$ inhibits the stimulatory effect of luteinizing hormone and prostaglandin E2 on progesterone secretion by the bovine corpus luteum. Domest. Anim. Endocrinol. 2011, 40, 183-191. [CrossRef]

48. Gregoraszczuk, E.; Zieba, D. Effect of estradiol-17 on basal and hCG progesterone secretion by porcine luteal in various stages of the luteal phase. Endocr. J. 1994, 41, 57-62. [CrossRef]

49. Gu, Y.; Chang, C.J.G.; Rikihisa, Y.; Lin, Y.C. Inhibitory effect of gossypol on human chorionic gonadotropin (hCG)-induced progesterone secretion in cultured bovine luteal cells. Life Sci. 1990, 47, 407-414. [CrossRef]

50. Gregoraszczuk, E.L.; Wojtusiak, A. Evaluation of the physiological value of porcine luteal cells isolated in various stages of the luteal phase: Tissue culture approach. Cytotechnology 1992, 8, 215-217. [CrossRef]

51. Pate, J.; Condon, W. Effects of prostaglandin F2a on agonist-indust progesterone production in cultured bovine luteal cells. Biol. Reprod. 1984, 31, 427-435. [CrossRef] 
52. Cannon, M.J.; Davis, J.S.; Pate, J.L. Expression of costimulatory molecules in the bovine corpus luteum. Reprod. Biol. Endocrinol. 2007, 5, 1-13. [CrossRef]

53. Livak, K.J.; Schmittgen, T.D. Analysis of relative gene expression data using real-time quantitative PCR and the $2^{-\Delta \Delta C T}$ method. Methods 2001, 25, 402-408. [CrossRef] [PubMed]

54. Jia, Y.; Li, Q.; Burris, W.R.; Aiken, G.E.; Bridges, P.J.; Matthews, J.C. Forms of selenium in vitamin-mineral mixes differentially affect serum prolactin concentration and hepatic glutamine synthetase of steers grazing endophyte-infected tall fescue. J. Anim. Sci. 2018, 96, 715-727. [CrossRef] [PubMed]

55. Wahlen, R.; Evans, L.; Turner, J.; Hearn, R. The use of collision/reaction cell ICP-MS for the determination of elements in blood and serum samples. Spectroscopy 2005, 20, 84-89.

56. Burk, R.F.; Hill, K.E. Regulation of selenium metabolism and transport. Annu. Rev. Nutr. 2015, 35, 109-134. [CrossRef]

57. Mattmiller, S.A.; Carlson, B.A.; Sordillo, L.M. Regulation of inflammation by selenium and selenoproteins: Impact on eicosanoid biosynthesis. J. Nutr. Sci. 2013, 2, 1-13. [CrossRef]

58. Veres, Z.; Tsai, L.; Scholz, T.D.; Politino, M.; Balaban, R.S.; Stadtman, T.C. Synthesis of 5-methylaminomethyl-2-selenouridine in tRNAs: 31P NMR studies show the labile selenium donor synthesized by the selD gene product contains selenium bonded to phosphorus. Proc. Natl. Acad. Sci. USA 1992, 89, 2975-2979. [CrossRef]

59. Glass, R.S.; Singh, W.P.; Jung, W.; Veres, Z.; Scholz, T.D.; Stadtman, T.C. Monoselenophosphate: Synthesis, characterization, and identity with the prokaryotic biological selenium donor, compound SePX. Biochemistry 1993, 32, 12555-12559. [CrossRef]

60. Xu, X.M.; Carlson, B.A.; Mix, H.; Zhang, Y.; Saira, K.; Glass, R.S.; Berry, M.J.; Gladyshev, V.N.; Hatfield, D.L. Biosynthesis of Selenocysteine on Its tRNA in Eukaryotes. PLoS Biol. 2006, 5, e4. [CrossRef]

61. Garrel, C.; Ceballos-Picot, I.; Germain, G.; Al-Gubory, K.H. Oxidative stress-inducible antioxidant adaptive response during prostaglandin F2alpha-induced luteal cell death in vivo. Free Radic. Res. 2007, 41, 251-259. [CrossRef]

62. Kato, H.; Sugino, N.; Takiguchi, S.; Kashida, S.; Nakamura, Y. Roles of reactive oxygen species in the regulation of luteal function. Rev. Reprod. 1997, 2, 81-83. [CrossRef]

63. Chen, Q.; Vazquez, E.J.; Maghaddas, S.; Hoppel, C.L.; Lesnefsky, E.J. Production of reactive oxygen species by mitochondria. J. Biol. Chem. 2003, 278, 36027-36031. [CrossRef] [PubMed]

64. Agarwal, A.; Gupta, S.; Sharma, R.K. Role of oxidative stress in female reproduction. Reprod. Biol. Endocrinol. 2005, 3, 28. [CrossRef] [PubMed]

65. Kawaguchi, S.; Sakumoto, R.; Okuda, K. Induction of the expressions of antioxidant enzymes by luteinizing hormone in the bovine corpus luteum. J. Reprod. Dev. 2013, 59, 219-224. [CrossRef] [PubMed]

66. Riley, J.C.; Behrman, H.R. Oxygen radicals and reactive oxygen species in reproduction. Proc. Soc. Exp. Biol. Med. 1991, 189, 781-791. [CrossRef]

67. Carlson, J.C.; Wu, X.M.; Sawada, M. Oxygen radicals and the control of ovarian corpus luteum function. Free Radic. Biol. Med. 1993, 14, 79-84. [CrossRef]

68. Hayashi, K.; Miyamoto, A.; Konari, A.; Ohtani, M.; Fukui, Y. Effect of local interaction of reactive oxygen species with prostaglandin F2 $\alpha$ on the release of progesterone in ovine corpora lutea in vivo. Theriogenology 2003, 59, 1335-1344. [CrossRef]

69. Al-Gubory, K.H.; Fowler, P.A.; Garrel, C. The roles of cellular reactive oxygen species, oxidative stress and antioxidants in pregnancy outcomes. Int. J. Biochem. Cell Biol. 2010, 42, 1634-1650. [CrossRef]

70. Sawada, M.; Carlson, J.C. Rapid plasma membrane changes in superoxide radical formation, fluidity, and phospholipase A2 activity in the corpus luteum of the rat during induction of luteolysis. Endocrinology 1991, 128, 2992-2998. [CrossRef]

71. Sugino, N.; Nakamura, Y.; Takeda, O.; Ishimatsu, M.; Kato, H. Changes in activities of superoxide dismutase and lipid peroxide in corpus luteum during pregnancy in rats. J. Reprod. Fertil. 1993, 97, 347-351. [CrossRef]

72. Vu, H.V.; Acosta, T.J. Catalase and glutathione peroxidase expression in bovine corpus luteum during the estrous cycle and their modulation by prostaglandin $\mathrm{F} 2 \alpha$ and $\mathrm{H}_{2} \mathrm{O}_{2}$. Anim. Reprod. 2014, 11, 74-84.

73. Vu, H.V.; Acosta, T.J.; Yoshioka, S.; Abe, H.; Okuda, K. Roles of prostaglandin F2alpha and hydrogen peroxide in the regulation of Copper/Zinc superoxide dismutase in bovine corpus luteum and luteal endothelial cells. Reprod. Biol. Endocrinol. $2012,10,87$. [CrossRef] [PubMed]

74. Vu, H.V.; Dam, T.V.; Acosta, T.J. Regulation of superoxide dismutase by prostaglandin F2alpha in the bovine corpus luteum. Anim. Reprod. 2013, 10, 88-98.

75. Nakamura, T.; Ishigami, T.; Makino, N.; Sakamoto, K. The down-regulation of glutathione peroxidase causes bovine luteal cell apoptosis during structural luteolysis. J. Biochem. 2001, 129, 937-942. [CrossRef] [PubMed]

76. Liang, H.; Ran, Q.; Jang, Y.C.; Holstein, D.; Lechleiter, J.; McDonald-Marsh, T.; Musatov, A.; Song, W.; Van Remmen, H.; Richardson, A. Glutathione peroxidase 4 differentially regulates the release of apoptogenic proteins from mitochondria. Free Radic. Biol. Med. 2009, 47, 312-320. [CrossRef]

77. Brigelius-Flohé, R.; Maiorino, M. Glutathione peroxidases. Biochim. Biophys. Acta 2013, 1830, 3289-3303. [CrossRef]

78. Souto, P.L.; Carmouy, L.S.T.; Santos, C.; Martins, E.; Martins, V.; Hatamoto-Zervoudakis, L.K.; Murad, A.M.; Mehta, A.; McManus, C.; Ramos, A.F. Seasonal differences in seminal plasma proteins from two bovine breeds adapted to a subtropical climate. Trop. Anim. Health Prod. 2021, 53, 61. [CrossRef]

79. Kuchenbaecker, K.B.; Ramus, S.J.; Tyrer, J.; Lee, A.; Shen, H.C.; Beesley, J.; Lawrenson, K.; McGuffog, L.; Healey, S.; Lee, J.M.; et al. Identification of six new susceptibility loci for invasive epithelial ovarian cancer. Nat. Genet. 2015, 47, 164-174. [CrossRef] 
80. Chen, Y.; Wang, K.; Zhang, D.; Zhao, Z.; Huang, J.; Zhou, L.; Feng, M.; Shi, J.; Wei, H.; Li, L.; et al. GPx6 is involved in the in vitro induced capacitation and acrosome reaction in porcine sperm. Theriogenology 2020, 156, 107-115. [CrossRef]

81. Dear, T.N.; Campbell, K.; Rabbitts, T.H. Molecular cloning of putative odorant-binding and odorant-metabolizing proteins. Biochemistry 1991, 30, 10376-10382. [CrossRef]

82. Kryukov, G.V.; Casellano, S.; Novoselov, S.V.; Lobanov, A.V.; Zehtab, O.; Guigó, R.; Gladyshev, V.N. Characterization of mammalian selenoproteomes. Science 2003, 300, 1439-1443. [CrossRef]

83. Burk, R.F.; Hill, K.E. Selenoprotein P- Expression, functions, and roles in mammals. Biochim. Biophys. Acta 2009, 1790, 1441-1447. [CrossRef] [PubMed]

84. Hart, C.G.; Camacho, L.E.; Swanson, K.C.; Vonnahme, K.A.; Lemley, C.O. Hepatic steroid metabolizing enzyme activity during early, mid, and late bovine pregnancy. Domest. Anim. Endocrinol. 2014, 49, 31-38. [CrossRef] [PubMed]

85. Alila, H.; Dowd, J.; Corradino, R.; Harris, W.; Hansel, W. Control of progesterone production in small and large bovine luteal cells separated by flow cytometry. J. Reprod. Fertil. 1988, 82, 645-655. [CrossRef]

86. Fitz, T.; Mayan, M.; Sawyer, H.; Gamboni, F.; Niswender, G. Characterization of two steroidogenic cell types in the ovine corpus luteum. Biol. Reprod. 1982, 27, 703-711. [CrossRef]

87. Harrison, L.M.; Kenny, N.; Niswender, G.D. Progesterone production, LH receptors, and oxytocin secretion by ovine luteal cell types on day 6, 10, and 15 of the oestrous cycle and day 25 of pregnancy. J. Reprod. Fertil. 1987, 79, 539-548. [CrossRef] [PubMed]

88. Kotwica, J.; Skarzynski, D.; Mlynarczuk, J.; Redawiecki, R. Role of prostaglandin E2 in basal and noradrenaline-induced progesterone secretion by the bovine corpus luteum. Prostaglandins Other Lipid Mediat. 2003, 70, 351-359. [CrossRef]

89. Weems, Y.S.; Bridges, P.J.; Sasser, R.G.; Ching, L.; LeaMaster, B.R.; Vincent, D.L.; Weems, C.W. Effect of mifeprestone on pregnancy, pregnancy-specific protein $\mathrm{B}(\mathrm{PSPB})$, progesterone, estradiol-17B, prostaglandin $\mathrm{F} 2 \alpha\left(\mathrm{PGF}_{2} \alpha\right)$ and prostaglandin $\mathrm{E}$ (PGE) on ovariectomized 90-day pregnant ewes. Prostaglandins Other Lipid Mediat. 2002, 70, 195-208. [CrossRef]

90. Hoyer, P.B.; Niswender, G.D. Adenosine 3',5'-monophosphate-binding capacity in small and large ovine luteal cells. Endocrinology 1986, 119, 1822-1829. [CrossRef]

91. De Rensis, F.; López-Gatius, F.; García-Ispierto, I.; Techakumpu, M. Clinical use of human chorionic gonadotropin in dairy cows: An update. Theriogenology 2010, 73, 1001-1008. [CrossRef]

92. Alila, H.W.; Corradino, R.A.; Hansel, W. A comparison of the effects of cyclooxygenase prostanoids on progesterone production by small and large bovine luteal cells. Prostaglandins 1988, 36, 259-270. [CrossRef]

93. Fitz, T.A.; Hoyer, P.B.; Niswender, G.D. Interactions of prostaglandins with subpopulations of ovine luteal cells. I. Stimulatory effects of prostaglandins E1, E2, and I2. Prostaglandins 1984, 28, 119-126. [CrossRef]

94. Fitz, T.; Mock, E.; Mayan, M.; Niswender, G. Interactions of prostaglandins with subpopulations of ovine luteal cells. II. Inhibitory effects of $\mathrm{PGF}_{2 \alpha}$ and protection by $\mathrm{PGE}_{2}$. Prostaglandins 1984, 28, 127-138. [CrossRef]

95. Pratt, B.R.; Butcher, R.L.; Inskeep, E.K. Antiluteolytic effect of the conceptus and of PGE 2 in ewes. J. Anim. Sci. 1977, 45, 784-791. [CrossRef] [PubMed]

96. Magness, R.; Huie, J.; Hoyer, G.; Huecksteadt, T.; Reynolds, L.; Seperich, G.; Whysong, G.; Weems, C. Effect of chronic ipsilateral or contralateral intrauterine infusion of prostaglandin E2 ( $\left.\mathrm{PGE}_{2}\right)$ on luteal function of unilaterally ovariectomized ewes. Prostaglandins Med. 1981, 6, 389-401. [CrossRef]

97. Henderson, K.; Scaramuzzi, R.; Baird, D. Simultaneous infusion of prostaglandin E2 antagonizes the luteolytic action of PGF 2 alpha in vivo. J. Endocrinol. 1977, 72, 379-383. [CrossRef]

98. Reynolds, L.P.; Stigler, J.; Hoyer, G.L.; Magness, R.R.; Huie, J.M.; Huecksteadt, T.P.; Whysong, G.L.; Behrman, H.R.; Weems, C.W. Effect of $\mathrm{PGE}_{1}$ on $\mathrm{PGF}_{2 \alpha}$-induced luteolysis in nonbred ewes. Prostaglandins 1981, 21, 957-972. [CrossRef]

99. Fernandes, M.S.; Pierron, V.; Michalovich, D.; Astle, S.; Thornton, S.; Peltoketo, H.; Lam, E.W.F.; Gellersen, B.; Huhtaniemi, I.; Allen, J.; et al. Regulated expression of putative membrane progestin receptor homologues in human endometrium and gestational tissues. J. Endocrinol. 2005, 187, 89-101. [CrossRef]

100. Gellersen, B.; Fernandes, M.S.; Brosens, J.J. Non-genomic progesterone actions in female reproduction. Hum. Reprod. Update 2009, 15, 119-138. [CrossRef]

101. Cook, C.; Kaltenbach, C.C.; Norton, H.W.; Nalbandov, A.V. Synthesis of progesterone in vitro by porcine corpora lutea. Endocrinology 1967, 81, 573-584. [CrossRef]

102. Cook, C.; Nalbandov, A.V. The effect of some pituitary hormones on progesterone synthesis in vitro by the luteinized ovary of the common opossum (Didelphis marsupialis virginiana). J. Reprod. Fertil. 1968, 15, 267-275. [CrossRef]

103. Kaltenbach, C.C.; Graber, J.W.; Niswender, G.D.; Nalbandov, A.V. Effect of hypophysectomy on the formation and maintenance of corpora lutea in the ewe. Endocrinology 1968, 82, 753-759. [CrossRef] [PubMed]

104. Hwang, J.; Menon, K.M.J. Characterization of low density and high density lipoprotein receptors in the rat corpus luteum and regulation by gonadotropin. J. Biol. Chem. 1983, 258, 8020-8027. [CrossRef]

105. Ohashi, M.; Carr, B.; Simpson, E. Lipoprotein-binding sites in the human corpus luteum membrane fractions. Endocrinology 1982, 110, 1477-1482. [CrossRef] [PubMed]

106. Pate, J.; Condon, W. Effects of serum and lipoproteins on steroidogenesis in cultured bovine luteal cells. Mol. Cell. Endocrinol. 1982, 28, 551-562. [CrossRef]

107. Brown, M.S.; Goldstein, J.L. A receptor-mediated pathway for cholesterol biosynthesis (Nobel Lecture). Science 1986, $25,583-602$. [CrossRef] 
108. Grummer, R.R.; Carroll, D.J. A review of lipoprotein cholesterol metabolism: Importance to ovarian function. J. Anim. Sci. 1988, 66, 3160-3173. [CrossRef]

109. Infante, R.E.; Wang, M.L.; Radhakrishnan, A.; Kwon, H.J.; Brown, M.S.; Goldstein, J.L. NPC2 facilitates bidirectional transfer of cholesterol between NPC1 and lipid bilayers, a step in cholesterol egress from lysosomes. Proc. Natl. Acad. Sci. USA 2008, 40, 15287-15292. [CrossRef]

110. Kwon, H.J.; Abi-Mosleh, L.; Wang, M.L.; Deisenhofer, J.; Goldstein, J.L.; Brown, M.S.; Infante, R.E. Structure of N-terminal domain of NPC1 reveals distinct subdomains for binding and transfer of cholesterol. Cell 2009, 137, 1213-1224. [CrossRef]

111. Wang, M.L.; Motamed, M.; Infante, R.E.; Abi-Mosleh, L.; Kwon, H.J.; Brown, M.S.; Goldstein, J.L. Identification of surface residues on Niemann-Pick C2 essential for hydrophobic handoff of cholesterol to NPC1 in lysosomes. Cell Metab. 2010, 12, 166-173. [CrossRef]

112. Sleat, D.E.; Wiseman, J.A.; El-Banna, M.; Price, S.M.; Verot, L.; Shen, M.A.; Tint, G.S.; Vanier, M.T.; Walkley, S.U.; Lobel, P. Genetic evidence for nonredundant functional cooperatively between NPC1 and NPC2 in lipid transport. Proc. Natl. Acad. Sci. USA 2004, 101, 5886-5891. [CrossRef]

113. Shen, W.J.; Azhar, S.; Kraemer, F.B. Lipid droplets and steroidogenic cells. Exp. Cell Res. 2016, 340, 209-214. [CrossRef] [PubMed]

114. Ferreri, K.; Menon, K.M.J. Characterization and isolation of a high-density-lipoprotein-binding protein from bovine corpus luteum plasma membrane. Biochem. J. 1992, 287, 841-848. [CrossRef] [PubMed]

115. Kraemer, F.B.; Shen, W.J.; Harada, K.; Patel, S.; Osuga, J.I.; Ishibashi, S.; Azhar, S. Hormone-sensitive lipase is required for high-density lipoprotein cholesteryl ester-supported adrenal steroidogenesis. Mol. Endocrinol. 2004, 18, 549-557. [CrossRef]

116. Cook, K.G.; Yeaman, S.J.; Stralfors, P.; Fredrikson, G.; Belfrage, P. Direct evidence that cholesterol ester hydrolase from adrenal cortex is the same enzyme as hormone-sensitive lipase from adipose tissue. Eur. J. Biochem. 1982, 125, 245-249. [CrossRef] [PubMed]

117. Yeaman, S.J. Hormone-sensitive lipase-New roles for an old enzyme. Biochemistry 2004, 379, 11-22. [CrossRef] [PubMed]

118. Cook, K.G.; Colbran, R.J.; Snee, J.; Yeaman, S.J. Cytosolic cholesterol ester hydrolase from bovine corpus luteum. Biochim. Biophys. Acta Mol. Cell Biol. Lipids 1983, 752, 46-53. [CrossRef]

119. Fredrikson, G.; Strålfors, P.; Nilsson, N.O.; Belfrage, P. Hormone-sensitive lipase of rat adipose tissue. Purification and some properties. J. Biochem. 1981, 256, 6311-6320. [CrossRef]

120. Fredrikson, G.; Tornqvist, H.; Belfrage, P. Hormone-sensitive lipase and monoacylglycerol lipase are both required for complete degradation of adipocyte triacylglycerol. Biochim. Biophys. Acta 1986, 876, 288-293. [CrossRef]

121. Selvaraj, V.; Stocco, D.M.; Clark, B.J. Current knowledge on the acute regulation of steroidogenesis. Biol. Reprod. 2018, 99, 13-26. [CrossRef]

122. Stocco, D.M.; Sodeman, T.C. The $30 \mathrm{kDa}$ mitochondrial proteins induced by homone stimulation in Ma-10 mouse Leydig tumor cells that are processed from larger precursors. J. Biol. Chem. 1991, 266, 19731-19738. [CrossRef]

123. Lin, H.; Sugawara, T.; Strauss III, J.F.; Clark, B.J.; Stocco, D.M.; Saenger, P.; Rogol, A.; Miller, W.L. Role of steroidogenic acute regulatory protein in adrenal and gonadal steroidogenesis. Science 1995, 267, 1828-1831. [CrossRef] [PubMed]

124. Clark, B.J.; Wells, J.; King, S.R.; Stocco, D.M. The purification, cloning, and expression of a novel luteinizing hormone-induced mitochondrial protein in MA-10 mouse Leydig tumor cells. Characterization of the steroidogenic acute regulatory protein (StAR). J. Biol. Chem. 1994, 269, 28314-28322. [CrossRef]

125. Mitani, F.; Shimizu, T.; Ueno, R.; Ishimura, Y.; Izumi, S.; Komatsu, N.; Watanabe, K. Cytochrome P-450011b and P-450scc in adrenal cortex: Zonal distribution and intramitochondrial localization by the horseradish peroxidase-labeled antibody method. $J$. Histochem. Cytochem. 1982, 30, 1066-1074. [CrossRef] [PubMed]

126. Hanukoglu, I.; Jefcoate, C.R. Mitochondrial cytochrome P-450scc: Mechanism of electron transport by adrenodoxin. J. Biol. Chem. 1980, 255, 3057-3061. [CrossRef]

127. Hanukoglu, I.; Spitsberg, V.; Bumpus, J.A.; Dus, K.M.; Jefcoate, C.R. Adrenal mitochondrial cytochrome P-450scc: Cholesterol and adrenodoxin interactions at equilibrium and during turnover. J. Biol. Chem. 1981, 256, 4321-4328. [CrossRef]

128. Hanukoglu, I.; Hanukoglu, Z. Stoichiometry of mitochondrial cytochromes P-450, adrenodoxin and adrenodoxin reductase in adrenal cortex and corpus luteum: Implications for membrane organization and gene regulation. Eur. J. Biochem. 1986, 157, 27-31. [CrossRef]

129. Labrie, F.; Simard, J.; Luu-The, V.; Bélanger, A.; Pelletier, G. Structure, function and tissue-specific gene expression of 3Bhydroxysteroid dehydrogenase/5-ene-4-ene isomerase enzymes in classical and peripheral intracrine steroidogenic tissues. $J$. Steroid Biochem. Mol. 1992, 43, 805-826. [CrossRef]

130. Aten, R.F.; Duarte, K.M.; Behrman, H.R. Regulation of ovarian anti-oxidant vitamins, reduced glutathione and lipid peroxidation by luteinizing hormone and prostaglandin F2 $\alpha$. Biol. Reprod. 1992, 46, 401-407. [CrossRef]

131. Behrman, H.R.; Aten, R.F. Evidence that hydrogen peroxide blocks hormone-sensitive cholesterol transport into mitochondria in rat luteal cells. Endocrinology 1991, 128, 2958-2966. [CrossRef]

132. Carlson, J.C.; Sawada, M.; Boone, D.L.; Stauffer, J.M. Stimulation of progesterone secretion in dispersed cells of rat corpora lutea by antioxidants. Steroids 1995, 60, 272-276. [CrossRef] 
133. Gatzuli, E.; Aten, R.F.; Behrman, H.R. Inhibition of gonadotropic action and progesterone synthesis by xanthine oxidase in rat luteal cells. Endocrinology 1991, 128, 2253-2258. [CrossRef] [PubMed]

134. Vega, M.; Carrasco, I.; Castillo, T.; Troncoso, J.L.; Videla, L.A.; Devoto, L. Functional luteolysis in response to hydrogen peroxide in human luteal cells. J. Endocrinol. 1995, 147, 177-182. [CrossRef] [PubMed] 